\title{
On the Artificial Culture of Marine Plankton Organisms.
}

\author{
$\mathrm{By}$
}

E. J. Allen, D.Sc.,

Director of Laboratories and Secrelary to the Council of the Marine Biological Association, and

\section{E. W. Nelson,}

Assistant Naturalist.

Introduction ,

I. Culture of Plankton Diatoms

A. Practical Culture Methods

1. Miquel's Method

2. Houghton Gill's Method

3. (a) Modification of Miquel's Method. "Miquel Sea-water" . 427

(b) English Channel Water . . . . . . . . 429

(c) Tank-Water . . . . . . . . . 430

(d) Animal-Charcoal Water . $\quad$. $\quad$. $\quad$. $\quad .431$

(e) Peroxide of Hydrogen Water . . . . . . 434

(f) Cultures in these Media . . . . . . 435

B. Experiments with a view to Determining the Conditions which underlie the successful Culture of Diatoms . . . . 436

Methods . . . . . . . . . 437

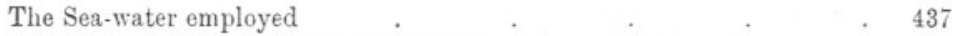

The Constituents of Miquel's Solutions . . . 438

Animal Charcoal and Peroxide of Hydrogen . . . 443

Reviving Exhausted Cultures . . . . . . 443

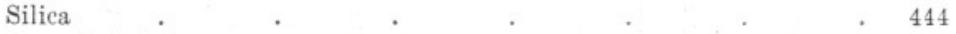

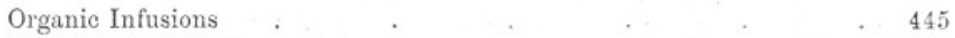

Artificial Sea-water . . . . . . . . . . 446

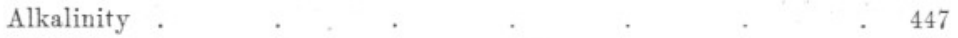

Salinity . . . . . . . . 453

Light . . . . . . . . . . 453

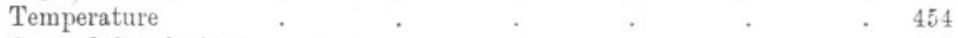

General Conclusions . $\quad . \quad$. $\quad . \quad . \quad 455$

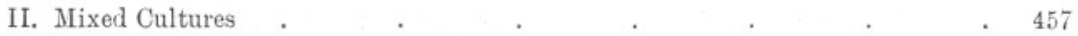

III. Notes on particular species of Diatoms, on their methods of Reproduction, and

on other Algre occurring in Cultures $\quad$. $\quad$. $\quad . \quad 4460$

IV. Rearing of Marine Larve . $\quad . \quad$. . . . $\quad 464$

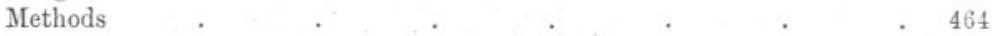

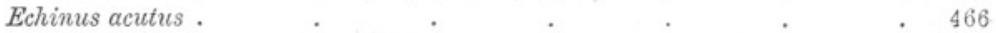

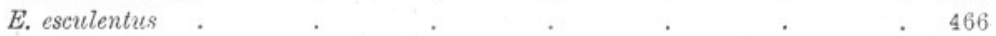

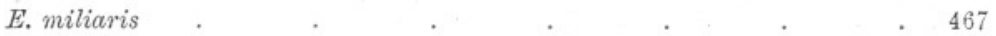

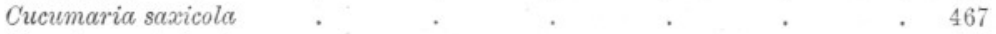

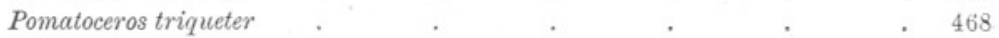

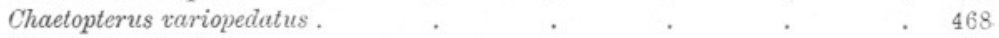

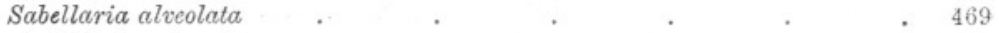

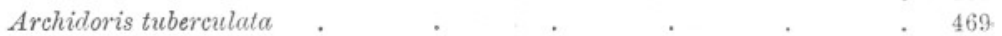


Calanus finmarchicus . . $\quad 470$

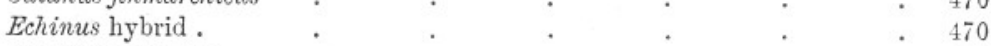

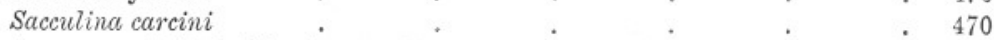

Bibliography .

Summary of Method for Rearing Larvæ $\quad . \quad 5 \quad . \quad 371$

Introduction. The observations to be recorded in this Paper were commenced in March, 1905. They originated in an attempt to find a general method for rearing marine larval forms. Several investigators had previously succeeded in rearing Echinoderms, Molluscs, and Polychætes from artificially fertilized eggs under laboratory conditions, but the process was generally difficult and the results more or less uncertain. The most promising method seemed to be that adopted by Caswell Grave (26), who was able to rear his larvæ by feeding them on diatoms. Grave obtained his diatoms by placing sand, collected from the sea bottom, in aquaria and using such diatoms as developed from this material. All the methods, however, suffered from the uncertainty of not knowing what organisms were introduced into the aquaria in which the larvæ were to be reared, either in the original sea-water or along with the food-supply.

It appeared, therefore, at an early stage of the work, worth while to make an attempt to carry out rearing experiments on a more definite and precise plan, to endeavour, in fact, to introduce the larvæ to be reared into sterile sea-water, and to feed them with pure cultures of a suitable food. This was the ideal to be aimed at. As a matter of fact, it has seldom, if ever, been attained in practice; nevertheless a considerable measure of success has been achieved by working upon these lines, and during the course of the work innumerable problems relating to the physical conditions under which plankton organisms can best flourish have presented themselves. Some account of the experiments made may be of interest to other workers, although many of the problems raised are not yet solved, notwithstanding the fact that some 1500 cultural experiments have been under observation. It is rather with a view of stimulating other work upon similar lines, than of bringing forward conclusive results, that this paper is being published.

In the summer of 1907, Mr. E. W. Nelson became associated with the investigation, and since that date the experimental work has been carried out by him. The discussions in this paper of a more chemical character, particularly the section on alkalinity, are almost entirely the work of Mr. Nelson, and we have both had throughout the advantage of the constant advice and help of Mr. D. J. Matthews on all such matters. 


\section{CULTURE OF PLANKTON DIATOMS.}

\section{A. Practical Culture Methods.}

1. Miquel's Method. Attention was first directed to the culture of Plankton diatoms; and the methods, which had been elaborated by Miquel (11) for fresh-water diatoms and had been found by him to succeed with marine-bottom diatoms, were tried.

The essential features of Miquel's method, as applied to marine diatoms, are as follows:-

Two solutions are prepared :-

\section{Solution A.}

Magnesium sulphate . . . . . $10 \mathrm{grm}$.

Sodium chloride . . . . . . 10 ,

Sodium sulphate . . . . . . . 5 ,

Ammonium nitrate . . . . . 1 ,

Potassium nitrate . . . . . . . 2 ,

Sodium nitrate . . . . . . . 2 "

Potassium bromide . . . . . . . 0.2 ,

Potassium iodide. . . . . . . 0.1 ,

Water . . . . . . . . 100 ,

\section{Solution B.*}

Sodium phosphate

Calcium chloride (dry)

Hydrochloric acid

Ferric chloride

Water

$$
\begin{gathered}
4 \text { grm. } \\
4 \quad, \\
+2 \text { cc. } \\
\ddagger 2 \Rightarrow \\
80 "
\end{gathered}
$$

Forty drops of Solution A and 10 to 20 drops of Solution B are added to each $1000 \mathrm{cc}$. of sea-water, and the sea-water is sterilized by keeping it at $70^{\circ} \mathrm{C}$. for about 20 minutes.

According to Miquel it is also necessary to add "organic nutritive material in the form of bran, straw, or filaments of weed such as Zostera. Macerations of these should be made up separately, some time before they are required for use, and should be carefully filtered and sterilized. Organic matter must, however, be used very sparingly,

* " The preparation of Solution A presents no difficulty ; Solution B should be made up as follows: To the Sodium phosphate dissolved in $40 \mathrm{cc}$. of water are added first the $2 \mathrm{cc}$. of Hydrochloric acid, then the $2 \mathrm{cc}$. of hydrous Ferric chloride and then the $4 \mathrm{grm}$. of Calcium chloride dissolved in $40 \mathrm{cc}$. of water, taking care to shake the mixture, which I call Phospho-ferro-calcic solution. The addition of this last solution to the maceration throws down a slight brownish flocculent precipitate, formed for the most part of Ferric oxide, which should be carefully separated from the liquid used for cultivations."

$\dagger$ " Acid chlorhydrique pur à $22^{\circ}$." Presumably meaning degrees Baumé=sp. gr. 1·169.

¥ " Perchlorure de fer liquide à $45^{\circ}$." As above=sp. gr. 1•421.

New series.-vol. vili. No. 5. March, 1910. 
or else putrefaction will set in and the cultures will be irrevocably lost." As a matter of fact, we have found that such organic infusions are unnecessary, when dealing with plankton diatoms, and it has not been our practice to employ them (cf., however, p. 445).

Miquel obtained cultures of single species of diatoms either by picking out individual diatoms under the microscope and introducing them into the prepared water, or by adding a small quantity of water containing a mixture of diatoms and other organisms to some prepared water, and subdividing this into a number of tubes. If the subdivision has been carried out sufficiently some of the tubes may contain one kind of diatom only, from which fresh cultures can be made. In this way, by repeated subdivision, cultures can be obtained which, by inoculating fresh quantities of prepared water from time to time, may, with care, be maintained indefinitely. Such cultures, however, must practically always contain bacteria, and Miquel distinguishes them from bacteria-free cultures, which he terms "Cultures des Diatomées a l'état de pureté absolue." The latter he found very difficult to obtain, but, through repeated washing in sterile water, followed by fractional subdivision, he succeeded in getting some in which he could find no trace of bacteria by ordinary bacteriological methods (cf. Miquel 11, p. 155 ; cf. also Richter, 16-18).

We propose to call any diatom culture, which can be carried on practically indefinitely by inoculating fresh supplies of prepared water, a "persistent" culture, the term "pure" culture being reserved for cultures which can be proved to contain not more than one organism. We are not satisfied that we have yet succeeded in obtaining cultures of the latter kind. For the most part our persistent cultures contain one species of diatom only, and are free from all organisms larger than small flagellates.

In our earlier experiments with plankton diatoms, we obtained persistent cultures, containing a single species of diatom, by both of the methods recommended by Miquel. We, however, have rarely succeeded by picking out single diatoms or chains of diatoms, for although we have passed the selected diatom through several changes of sterilized sea-water, the resulting cultures, even when the diatoms have multiplied to some extent, have generally shown evidence of contamination by harmful organisms, and have soon died down. Only in one of the earliest experiments, and in one more recent, has complete success resulted. In the first case a small chain of six or eight frustules of Skeletonema costatum, picked out in April, 1905, gave rise to a culture which still persists (Nov., 1909). Subcultures can still be obtained even from the original flask inoculated in April, 1905. In the 
second case a chain of 8 or 9 cells of Chaetoceras densum, picked out from a Petri dish culture, has given a particularly good growth.

The method of dilution and subdivision has been more successful and persistent cultures of a number of species have been obtained in this way.

A more ready method of obtaining the cultures is, we have found, to add one or two drops of plankton to, say, $250 \mathrm{cc}$. of a suitable sterile culture medium, and to pour this into shallow glass dishes (Petri dishes). The dishes should be placed in a position as free as possible from vibration, and where they can be easily examined with a lens in situ. The temperature should be kept as constant as possible and the dishes exposed to light of moderate intensity, direct sunlight being avoided. In the course of a few days, colonies of diatoms of different species will be seen at different spots on the bottom of the Petri dishes. These can be picked out with a fine pipette and transferred to flasks containing fresh culture medium. The colonies should be picked out from the Petri dishes at as early a stage as possible, because if left too long some one organism, a diatom or a flagellate, may have multiplied so rapidly that the whole of the water in the dish becomes infected with it. In this case persistent cultures of a single species would not be obtained. The above method is similar to one described by Miquel, excepting that he placed gelatinous silica at the bottom of the vessel. Some very successful persistent cultures were obtained from the following experiment, which will serve to illustrate the method:-A sample of plankton, from a very fine-mesh bolting-silk tow-net, was diluted down with sterile sea-water, until a single drop examined under a two-thirds-inch objective contained on an average ten organisms, chiefly diatoms of various species. Petri dishes (4 in.), containing 60 cc. each of Miquel sea-water, were then inoculated with various numbers of drops of the diluted plankton. The two dishes, to which two and three drops respectively were added, gave the best results; and from these persistent cultures of several species of diatoms were obtained. Hence we may conclude that the most advantageous number of single cells or short chains of cells to be added to a 4 in. Petri dish, containing $60 \mathrm{cc}$. culture medium, is about 20 to 30 .

We have succeeded in obtaining the following species of Plankton diatoms in persistent cultures :-

Asterionella japonica, Cleve.

Biddulphia mobiliensis (Bail.), Grun.

Biddulphia regia (M. Schultze).*

* See pp. 461. 


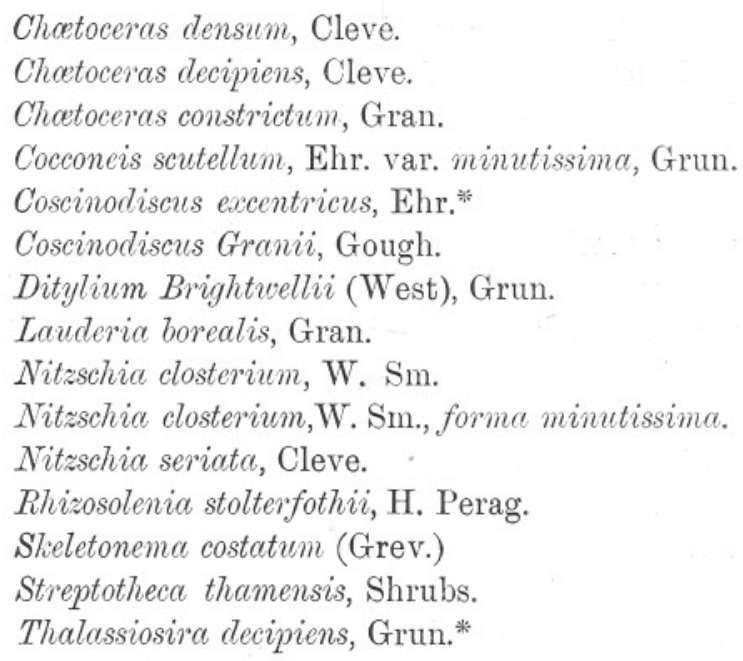

It is hardly necessary to add that in dealing with these cultures, similar precautions to those used in bacteriological work must be taken, all vessels and instruments being carefully sterilized before they are brought into contact with the prepared sea-water. The cultures are best made in small, wide-mouthed flasks, which may be plugged with cotton wool, or simply covered with watch-glasses. The flasks should be kept at as uniform a temperature as possible (from $12^{\circ}-17^{\circ}$ C.) and should be exposed to strong daylight, direct sunlight being avoided. A flask should not be more than half filled with culture fluid, so that the surface exposed to the air may be large in proportion to the volume of fluid.

Other Methods. The addition of the solutions devised by Miquel to. sea-water has in all cases given us good cultures of diatoms, and the method is certain in its action. We have, however, made numerous experiments by treating sea-water in other ways, with a view to. finding out what are the best conditions under which plankton diatoms will grow, and of arriving at some explanation of the action: of the different salts contained in Miquel's solutions.

2. Houghton Gill's Method. H. Houghton Gill (5), a contemporary of Miquel, made use of a culture medium not essentially different from that employed by the latter. Unfortunately he died before publishing his work, but an account of his principal results is given by Van Heurck. In his final method Houghton Gill made use of fourdistinct solutions, as follows:- 


\section{Solution 1.}

Crystallized sodium phosphate . . . . 2 grm.

Calcium chloride . . . . . . 4 ,

Syrup of iron chloride. . . . . . . 0.5\%

Strong hydrochloric acid . . . . . . 1 "

Water . . . . . . . 100 ",

Solution 2.

Crystallized magnesium sulphate . . . . . 4 "

, sodium sulphate . . . . . 4 ,

" potassium nitrate . . . . 4 ,

Common salt (sodium chloride) . . . . 8 "

Potassium bromide . . . . . . . 0.2 ,

Potassium iodide . . . . . . . . 0.2 ",

Water . . . . . . . 100 "

Solution 3.

Crystallized sodium carbonate - . . . 4 ,

Water . . . . . . . . 100 ,

\section{Solution 4.}

Well-washed, precipitated calcium silicate . . 25 ,

Water . . . . . . . . 75 ,

All the salts employed must be chemically pure. Three cc. of each of these liquids are added to $1000 \mathrm{cc}$. of fresh water or sea-water (according to circumstances), and the whole sterilized. In his earlier work Houghton Gill added a sterilized infusion of grass or of diatoms, but it is not clear from the accounts whether this was still employed with the above solutions. We have obtained very good cultures with the above solutions, to which we did not add any organic infusion.

3 (a). Modification of Miquel's method. "Miquel Sea-water."

Since several of the components in Miquel's formula for solution A (p. 423) are obviously unnecessary, when sea-water is being used as the basis of the culture-medium, we adopted for our own work the following modifications:-After some preliminary experiments it was found, as would be expected from the composition of sea-water, that the only salts of value to the medium are the three nitrates, $\mathrm{KNO}_{3}$, $\mathrm{NaNO}_{3}, \mathrm{NH}_{4} \mathrm{NO}_{3}$, and possibly $\mathrm{KBr}$ and $\mathrm{KI}$. The omission of the two latter was soon found to make no difference. Experiments also showed that the formula for solution A could, without any appreciable detriment to results, be further simplified to the one salt, $\mathrm{KNO}_{3}$, or $\mathrm{NaNO}_{3}$, but not $\mathrm{NH}_{4} \mathrm{NO}_{3}$. At first the amount of $\mathrm{KNO}_{3}$, dissolved in 100 cc. distilled water, used to make the modified solution $\mathrm{A}$, was the same as the sum of the weights of the nitrates in 
Miquel's own formula, viz. 5 grm. But later experiments showed that a considerably greater concentration of $\mathrm{KNO}_{3}$ than this gave more lasting cultures; the strength of solution, and amount to be added to a litre of sea-water, in order to obtain the best results, being 2 cc., $2 \mathrm{M}, \mathrm{KNO}_{3}$.

In the case of solution $\mathrm{B}$ no modification has been adopted, but it has been found that small variations in the amounts of the ingredients used do not affect the results. A convenient method for measuring the right amount of $\mathrm{FeCl}_{3}$ is to warm the salt until it just melts in its own water of crystallization, and to pipette out 2 cc. with a previously warmed pipette. No temperature corrections need be considered. Also $2 \mathrm{cc}$. of the ordinary pure concentrated hydrochloric acid at room temperature will suffice.

Our own formula for preparing Miquel sea-water is now :-

\section{Solution A.*}

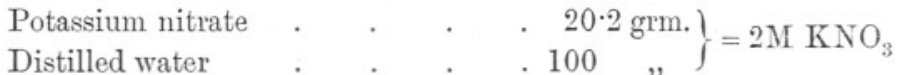

Solution B.†

Sodium phosphate $\left(\mathrm{Na}_{2} \mathrm{HPO}_{4} 12 \mathrm{H}_{2} \mathrm{O}\right) \quad 4$,

Calcium chloride $\left(\mathrm{CaCl}_{2} 6 \mathrm{H}_{2} \mathrm{O}\right)$. . 4 ,

Ferric chloride (melted) . . . $2 \mathrm{ce}$.

Hydrochloric acid (pure, concentrated) $2 \mathrm{cc}$.

Distilled water . . . . $80 \mathrm{cc}$.

To each 1000 cc. of sea-water $\ddagger$ add 2 cc. solution $A$ and 1 cc. solution $\mathrm{B}$, and sterilize by heating to $70^{\circ} \mathrm{C}$. When cool, decant off the clear liquids from the precipitate, which will have formed when solution $\mathrm{B}$ is added to the sea-water.

As a rule our cultures were made in $60 \mathrm{cc}$. of this medium, contained in short-necked, wide-mouthed flasks of 125 cc. capacity, so that the proportion of air-surface to volume of liquid was large.

The medium was found to give constantly satisfactory results. On inoculation from a persistent culture of such diatoms as Thalassiosira, Skeletonema, Chaetoceras, etc., a growth visible to the eye is obtained in about ten days, and then multiplication takes place very rapidly. In from three weeks to a month's time a very considerable growth will be seen making a brown, flocculent mass at the bottom and back of the vessel containing the culture.

* This strength has only been used in the most recent experiments; and solution $\mathrm{A}$ in this paper, unless otherwise stated, means the five per cent solution of $\mathrm{KNO}_{3}$.

$\dagger$ For preparing this solution see p. 423 .

¥ "Miquel water" seems to succeed equally well, whether it is made by adding Miquel's solutions to "outside water" or to "tank water" (cf. p. 437). 
In from three to four months the culture begins to show signs of exhaustion and the frustules lose colour, but they do not, as in the case of sterilized outside and tank water, completely die off. A great number certainly do die, but some remain in a resting condition, and often, after a period of six months or so, these begin to multiply again and the culture regains its former vigour. This is probably due to the food-stuffs contained in the dead frustules going into solution again, possibly by means of bacterial action. This periodicity in cultures is interesting in that it resembles what takes place in the ocean. Cultures in this medium will persist indefinitely, so far as our experience goes. The oldest culture in our possession is one of Skeletonema costatum, made at the very commencement of this work, dated April, 1905. Although the frustules in this culture are quite unrecognizable as any diatom now, on making a subculture in fresh Miquel a normal and healthy growth can always be obtained.

In old cultures the diatoms are nearly always found to be very much deformed, and often appear to be only a mass of broken-down chromatophores. Whether regeneration can be successfully obtained from a single chromatophore, which must presumably be contained within a cell-wall of some kind, has not been definitely decided, but results seem to point in this direction.

At the start of a culture a tendency to teratological forms is often exhibited, but when the growth is well advanced, the shape of the frustules is usually quite normal.

(b) English Channel Water ("Outside Water").-In a large number of our experiments sea-water brought in from outside the Plymouth breakwater, and therefore taken at some distance from the shore, has been used. This is referred to as "outside water." It has an average salinity of about $35.0 \%$, and the temperature range for the year is from $8^{\circ} \mathrm{C}$. to $16^{\circ} \mathrm{C}$.

If a sample of "outside water" is inoculated from a persistent culture of a plankton diatom, a small growth is obtained in from five to fifteen days. But soon minute bottom forms of diatoms, other algæ, flagellates, infusoria, etc., appear, and the inoculated species is lost. The total growth of any form is never large. If the growth of these foreign forms is prevented by sterilizing the water before inoculation, a considerably better growth of the plankton form is obtained. The water was, as a rule, sterilized by simply heating to $70^{\circ} \mathrm{C}$., which temperature was found to be quite adequate. Boiling gave equally good results, but the former was preferred, as less concentration due to evaporation took place. Even under these conditions 
no permanent culture can be obtained, the diatoms soon beginning to lose colour and getting into an exhausted condition. Death takes place in from two to three months after the culture has been started, and in many cases considerably sooner. Long before inability to start new cultures, the test of death, has been established, the valves appear on examination quite colourless and practically empty.

Samples of outside water, taken at times when the quantity of plankton was widely different, gave no appreciable variation in the results obtained by culture methods. It is, however, doubtful whether differences in the amounts of growth in cultures, proportional to the seasonal variation in the quantity of phytoplankton, would be sufficiently marked to be appreciable.

The total growth under cultural conditions, although small for a culture, is very much greater than any natural plankton that has come within our experience.

(c) Tank-water.- "Tank-water" or water taken from the supply of sea-water circulating through the tanks of the Aquarium at Plymouth, shows some striking and interesting differences from "outside water." This water is pumped up from the sea, just below the Laboratory, into two large, covered-in, settling reservoirs, with a capacity of 50,000 gallons each. Pumping is only done at high water, spring tides, so as to get the least contaminated water, and no water is pumped that does not show a specific gravity, measured with a hydrometer, of $\rho^{17.5}=26.00$ $(\mathrm{S}=34.00)$ or over. The water is allowed to settle for about a fortnight before being used for the general circulation.

The tanks themselves are made of slate and glass, and the pipes which convey the sea-water to them are of vulcanite, so that the water does not come in contact with metal, excepting in the pumps, which are of cast-iron. The two settling reservoirs are used alternately, for about a week each. From time to time, tide and water allowing, waste is replenished, and about twice a year each reservoir is emptied, cleaned out and refilled. The aquarium takes about 20,000 gallons, and this is in circulation with one of the two 50,000-gallon reservoirs. An estimate of the amount of life in the tanks of the aquarium must be exceedingly rough, but the intensity of the larger forms of life is far greater than anything met with in natural waters. About 500 fish and 2000 invertebrates, including all forms as large as an Actinia equina, might be somewhere near the mark. So it will be seen that the accumulation of excretory products must be a by no means negligible factor. The flora of the tanks is very restricted, and is chiefly composed of minute forms of algæ. Minute naviculoid diatoms, 
Ectocarpus, Cladophora, Enteromorpha, Vaucheria, and unicellular algæ are the commonest forms. The large seaweeds, such as Fucus and Laminaria, do not live long if introduced. Plankton diatoms, although a great number must be pumped up when the reservoirs are being filled, are not represented.

As in the case of outside water, a sample of "tank-water," inoculated from a persistent culture, will only give a very small growth, minute forms, etc., soon multiplying and choking out the plankton form. The ultimate growth of minute unicellular algæ other than diatoms is often considerable, and many quite unknown and unidentified forms have been obtained. The total growth of vegetable forms is always found to be greater than in the case of outside water.

In cultures of plankton diatoms made with sterilized tank water, a very great improvement on outside sterilized water was always noted. The culture of the diatom used to inoculate this medium persists for a considerable period, and the colour of the frustules remains normal for two to three months.

(d) Animal-Charcoal Water.-The use of animal charcoal, as a means of purifying the water in small aquaria, has for a long time been known and practised by those who have kept such aquaria in inland places. At an early stage in our experiments, water from a tank, which was not in a satisfactory condition, was treated with some powdered animal charcoal and filtered. It was noticed that a good growth of diatoms took place in this water. Systematic experiments with the use of animal charcoal were then commenced, and these have resulted in a method of great value, both for the culture of diatoms and for the rearing of pelagic larvæ.

Animal charcoal is made by the carbonization of bones," and is sold in two grades known as "pure" and "commercial." Our earlier experiments were all made with "pure" animal charcoal, but subsequently the "commercial" animal charcoal was largely used and appears to give equally good, if not better resuits. In both cases the animal charcoal is used in the powdered form. Animal-charcoal water is prepared as follows:-

1. A quantity of sea-water is sterilized by heating it in a flask to

* Analysis of Animal Charcoal, from Thorpe's Dictionary of Applied Chemistry :Carbon . . . . . . . 10.51

Ca., Mg. phosphates, Ca. fluoride, etc. . $80 \cdot 21$

Calcium carbonate . . . . . 830

Other nineral matter $\quad$. $\quad . \quad$. 0.98 
$70^{\circ} \mathrm{C}$, at which temperature it should be kept for about twenty minutes. At the same time some animal charcoal is heated sufficiently to sterilize but not to burn it, covered over and allowed to cool. When both are quite cold, the charcoal is added to the water (ca. $15 \mathrm{grm}$. to $1000 \mathrm{cc}$.) and well shaken up in it several times, After an interval of half an hour or more the water is filtered through fine filter cloth,* the whole filter having been first sterilized with boiling sea-water, and is received in a sterile flask. It is then ready for use.

2. For many experiments, where larger quantities of water were required, the sea-water was not sterilized before being treated with animal charcoal. In this case, if the first part of the filtrate be rejected, the subsequent water will generally be practically sterile, and few, if any, extraneous organisms will develop in it.

3. At a later date an automatic apparatus was set up in the Plymouth Laboratory, by which very considerable quantities of seawater could be treated with animal charcoal, and subsequently filtered through a "Berkefeld" filter; water treated in this manner we call "Berkefeld water." -Tank-water was always used in this apparatus, and was mixed with animal charcoal, $\dagger$ in a clean sulphuric acid carboy, by blowing air through with a pair of bellows. The mixture was allowed to settle for at least twenty-four hours and then syphoned over into an inverted bell-jar, with a tubulure at the bottom, into which the Berkefeld candle was fitted. Filtration under these conditions was found to be rather slow; so, in order to increase its rate, an apparatus was devised by which the pressure on the filter was considerably augmented.

This apparatus (see Fig. 1) consists of a glazed earthenware "tobacco jar" with two tubulures, one at the side, the other at the bottom, and a lid which can be screwed down tightly on to a rubber washer, by means of a triangular metal arrangement fitting into grooves above the lid. + The internal dimensions of our jars are $11 \times 6$ inches, and the diameter of the opening at the top is $3 \frac{1}{4}$ inches. The tubulures are coned, with the smaller diameter external, and make a good fit for a No. 8 rubber bung. When setting up this apparatus, a bung, through which a short glass tube bent at right angles is passed, is fitted into the

* The filter cloth used for this purpose is the same as is made for use in filter presses, and is known as Extra-Super Swansdown. To prevent this becoming clogged another cloth, known as Hydraulic Twill, was, as a rule, used over it.

$+\mathrm{Ca} .300 \mathrm{grm}$. to 20 litres of water.

‡ These jars were made, to our specification, by Messrs. Price, Powell, and Co., Bristol. The clamps usually supplied with such jars are not strong enough to obtain a tight joint, but these are easily replaced by stronger ones. 
side tubulure. This tube is connected, by means of rubber pressure tubing, to another glass tube leading down from the bottom of a small inverted bell-jar, placed some height above (in our case 14 feet, which gives a pressure of ca. 6 lbs. to the square inch inside the jar). A screw pinch-cock on this connection serves as a tap. The carboy containing the treated water stands just above the bell-jar, and is fitted with a tightly fitting rubber bung, through which two tubes pass. One is an ordinary syphon, the other the only air inlet into the carboy. This latter automatically keeps the level of the water in the bell-jar
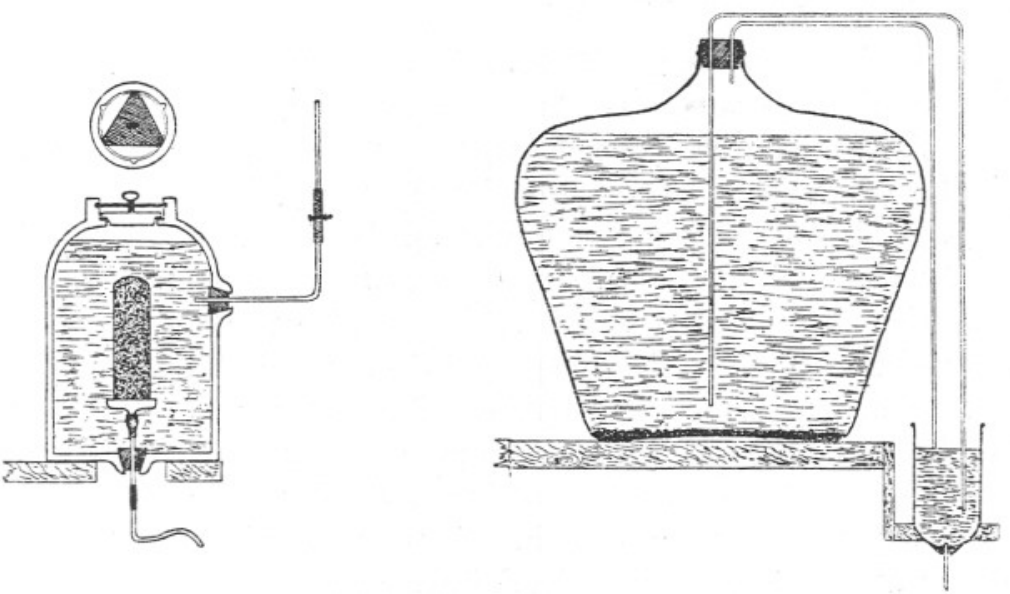

FIG. 1.-Diagram of apparatus for preparing sterile sea-water by filtration, without contact with metal.

constant, by closing the air-inlet as soon as the water covers the end of the tube. When filtering water, the modus operandi is as follows :-

The carboy is filled with tank-water, treated, and allowed to settle as before. The Berkefeld candle,* bung, delivery tube, and connections (see Fig. 1) are sterilized by boiling for half an hour and fitted into place from within. (The delivery tube is shaped so that any drops of water, accidentally running down outside it, do not enter the vessel receiving the filtrate; and the jar should be large enough to allow the hand to fit the filter into place without much trouble.) The pinch-cock is closed and the syphon from the carboy started, which will automatically stop if the bung has been properly fitted. This should be watched to avoid accidents. The pinch-cock is then opened until the water rises in the jar well above the top of the candle, but still leaving some air space. The lid can now be fitted into place and screwed down. The tightness of this joint can be tested by pouring a little water into

* No. 5. Porcelain mount; length 8 ins., diameter 2 ins. 
the crack round the lid, and observing if any bubbles are formed when the pinch-cock is opened. If all is right, no bubbles will be seen, and a good stream of water will flow out from the delivery tube. Our apparatus will filter about twenty litres an hour, and the filtrate is exceptionally bright and clear. The candle should be sterilized every three or four days that the apparatus is in use, to avoid indirect contamination by growths of organisms through the substance of the filter.* The water while passing through this apparatus only comes into contact with glass, earthenware, and rubber, the use of metal having been purposely avoided.

(e) Peroxide of Hydrogen Water. As it seemed probable that the action of animal charcoal was due to contact oxidation with the oxygen occluded in the charcoal, experiments were made to determine whether a similar effect could be produced by the use of hydrogen peroxide $\left(\mathrm{H}_{2} \mathrm{O}_{2}\right)$. This was used in two ways. In the first method a sufficient quantity of $\mathrm{H}_{2} \mathrm{O}_{2}$ was added to the sea-water to ensure complete sterilization ( $1 \mathrm{cc}$. of $\mathrm{H}_{2} \mathrm{O}_{2}$ of 20 vols. strength per 1000 cc. of tankwater was found to be satisfactory), and the excess of $\mathrm{H}_{2} \mathrm{O}_{2}$ was decomposed by adding manganese dioxide. The water was then filtered through filter cloth, and the filtrate appeared to remain quite sterile. Good cultures of Chaetoceras constrictum, Biddulphia mobiliensis, and Skeletonema costatum were made in this water, which seemed to be as good as water treated by the animal-charcoal method.

The second way of using the peroxide of hydrogen was to start with water sterilized by heating to $70^{\circ} \mathrm{C}$., and to add to this $\mathrm{H}_{2} \mathrm{O}_{2}$, in small quantities at a time, until its presence could just be detected on testing the sea-water with permanganate of potash. In these circumstances, the first amounts of $\mathrm{H}_{2} \mathrm{O}_{2}$ are decomposed in the oxidation of organic substances in the water, and a very slight excess of $\mathrm{H}_{2} \mathrm{O}_{2}$ persists. For tank-water 1 cc. of 1 vol. $\mathrm{H}_{2} \mathrm{O}_{2}$ per 1000 cc. was found to give the best general effect. Cultures grown in water prepared in this way developed satisfactorily, being practically equal to those made in animalcharcoal water, but they became exhausted rather quickly.

The treatment of aquarium water with ozone was also tried, as this seems to offer a possibility of treating large quantities of water, $\dagger$ such as the whole bulk of water in an aquarium circulation, without very considerable expense. Experiments on a small scale, which we were able to make, unfortunately only with imperfect apparatus, showed

* See Bulloch and Craw., Jour. of Hygiene, VI, No. 3 (1906) p. 409.

$\dagger$ The use of ozonized air for the purification of fresh water for town-water supplies has been adopted in some localities. See Bridge, J. H. Paper read before Franklin Institute, reprinted in English Mechanic (1907), pp. 369 and 392. 
that water treated with ozonized oxygen gave distinctly better cultures than untreated water. Although the sea-water was not absolutely sterilized by the treatment to which we actually subjected it, a sample of water which was visibly clouded with bacteria became quite clear and bright.

( $f)$ Cultures in these Media. In order to make clear the different results, which are obtained by using these different waters, we will describe the probable result which would be got from a series of flasks set up with the following media, and each inoculated with a persistent culture of a true plankton diatom, such as Thalassiosira, Skeletonema, or Chaetoceras.

A. "Outside water" untreated.

Small growth in from five to fifteen days, almost immediately swamped by growths of foreign forms; the latter, however, will never be large.

B. "Outside water" sterilized.

Slightly larger growth, very soon becoming exhausted.

C. "Tank-water" untreated.

Same result as in A, but growths will be much larger, healthier, and will last longer.

D. "Tank-water" sterilized.

A fair growth of the inoculated species, but the total growth will not be as great as in $\mathrm{C}$; the diatoms will retain their normal appearance for some time.

E. "Outside water" + Miquel's solutions A and B, sterilized.

Best culture in series, both in quantity and quality. The diatoms will remain normal and healthy for a very long period.

F. "Outside water" sterilized and treated with Animal Charcoal.

Fair growth, especially at first; diatoms will soon grow pale and become exhausted; better than D.

G. "Tank-water" sterilized and treated with Animal Charcoal.

As F, only growth will be slightly greater and will last considerably longer. Third best in series.

H. "Tank-water" treated with Animal Charcoal and filtered through Berkefeld filter.

This will usually be the second-best culture in the series, but the difference between this and $\mathrm{G}$ will only be slight.

K. "Outside water" treated with $\mathrm{H}_{2} \mathrm{O}_{2}$.

This will most resemble F, but will not be quite so good.

L. "Tank-water" treated with $\mathrm{H}_{2} \mathrm{O}_{2}$.

A distinct improvement over $\mathrm{K}$. This medium is rather variable, and in some cases the growth obtained has been quite equal to $\mathrm{F}$, if not. better. 


\section{B. Experiments with a View to Determining the Conditions Which underlie the successful Culture of Diatoms.}

The attempt to make cultures of diatoms for use as food, when rearing pelagic larvæ, led naturally to an effort to determine the best culture medium and the most favourable conditions for the rapid and continuous growth of diatoms. Before success can be attained in this direction exact knowledge as to the nature of the essential food-stuffsand in fact as to the general physiology of the Diatomaceæ-is necessary.* Numerous experiments, extending over the last three years, have been carried out, with a view to obtaining such knowledge, and the results, though still by no means complete or conclusive, are perhaps worth recording.

A great difficulty which has to be met in carrying out such investigations on marine diatoms is caused by the fact that, when sea-water is used as a basis for the culture media, we are dealing with a solution of a very complex and very variable character, the exact nature of which it is extremely difficult to determine. The most direct method of research, namely, chemical analysis, has not proved of much service, owing to the uncertainty and in many cases impossibility of accurate determinations, in sea-water, of such minute quantities of substances as those upon which the growth of plankton diatoms has been found to depend.

We have had, therefore, to rely, for the most part, on the lengthy and tedious process of analysis by "trial and error," the experiments being largely conducted on lines suggested by Liebig's well-known "law of minimums" (Pfeffer, vol, i., p. 413). The ideal at which we aim is to find a culture medium, with artificially prepared sea-water as its, basis, such that the absence, or diminution in quantity, of any one of its constituents would have a profound effect upon the growth of diatoms in it. Whether the conditions regulating growth in such a medium would be at all comparable to the natural conditions of life in the sea is a question that would have to be decided by experiment, but in any case this could be made a starting point for much more definite research than has yet been attempted. Up to the present time we have not, unfortunately, succeeded in finding such a culture medium. Throughout the work we have had very great difficulty, in spite of much care and many precautions, in obtaining consistent results. It may even happen that, in two flasks containing the same culture medium, inoculated with the same culture of diatom and standing side

* For general references to literature see Bibliography, especially Miquel (12), Richter (18). 
by side, under exactly identical conditions, as far as can be recognized, quite different degrees of growth will be observed. All experiments must therefore be frequently repeated before entire confidence can be felt in any conclusions which they seem to indicate.

It nust be remembered, also, that in all the persistent cultures of diatoms that we have used, bacteria have probably been present, and this fact has probably had some influence on the result. Unfortunately our attempts to obtain absolutely pure cultures have not met with success.

Methods. In carrying out the experiments to be described in this section the procedure has been as follows:-All media have been prepared from sterile sea-water, and sterile vessels and instruments have always been used. The cultures have usually been made in $60 \mathrm{cc}$. of liquid, in short-necked, wide-mouthed flasks of 125 cc. capacity. When a number of cultures were to be compared, the flasks were kept standing in a row together in such a way as to keep the physical conditions as similar as possible. Control cultures in standard media were included in each series, so that results from different series could be compared by reference to the controls. The various media were inoculated from a persistent culture of a species of plankton diatom, which in the great majority of cases was Thalassiosira decipiens (p. 460). When preparing the different media the methods used were, as far as possible, identical, and although only about $60 \mathrm{cc}$. was needed for a culture, a litre was made up, so that errors due to measuring very minute quantities might be avoided. The media were all freshly prepared for each comparative series of cultures, the same sample of sea-water being used, when the basis of any two or more was the same. Comparative estimates of the amount of growth in the different cultures were made by eye alone. Any difference between amounts of growth that has been described here as appreciable has always been accompanied by a marked difference in appearance to the eye on holding the cultures up to the light. A few drops from each culture were also, from time to time, examined microscopically as a test of the quality and purity of the growth.

The sea-water employed. The sea-water employed as a basis for the culture media has been either (1) "outside water" or (2) "tank-water." A general description of these will be found on pp. 429-431. An accurate chemical analysis of both types of water would probably make clear many difficult points, but, as already pointed out, no chemical methods of sufficient delicacy have yet been devised. 
We have seen that if we compare "tank-water," i.e. water from the closed circulation of the Plymouth Aquarium, with off-shore sea-water in situ, a most obvious difference is the much increased density of the larger forms of animal life in the former, combined with the almost complete absence of plant life. Hence the concentration of excretory products in the tank-water must be very much higher than in outside water. Other factors, such as increased bacterial action, artificial aeration, etc., in tank-water, must also be taken into account (cf. Vernon, 58; Smith, 56). There seems to be direct evidence to show that the concentration of nitrates, possibly due to the action of nitrifying bacteria on the products of excretion, such as urea, ammonia, etc., is considerably higher in the tank-water, and the presence of soluble organic matter, in concentrations never met with in the sea, can almost certainly be assumed. It is probably due to the presence of these nitrates and soluble organic substances that sterilized tank-water is a much better medium in which to grow diatoms than sterilized outside water (see p. 435).

The constituents of Miquel's solutions. It has already been stated that no better medium for the culture of plankton diatoms has been found by us than the solutions recommended by Miquel, although these solutions may be modified and simplified in various ways with equally good results. The formulæ recommended by Houghton Gill give very similar cultures. The essential features of Miquel's and Houghton Gill's methods, when adapted to sea-water, are the same. Miquel's solution A, and Gill's solution 2, can both be replaced by a solution of potassium nitrate (p. 427). Again, Miquel's solution B and Gill's solution 1 only differ in the proportionate amounts in which the various constituents are prescribed. The formulæ are:-

\begin{tabular}{|c|c|c|c|c|}
\hline & & & Miquel's sol. B. & H. Gill's sol. 1. \\
\hline $\mathrm{Na}_{2} \mathrm{HPO}_{4}, 12 \mathrm{H}_{2} \mathrm{O}$ & & . & . $\quad 4 \mathrm{grm}$ & $2 \mathrm{grm}$ \\
\hline $\mathrm{Ca} \mathrm{Cl}_{2}$ & $\cdot$ & . & $4 "$ & 4, \\
\hline $\mathrm{Fe} \mathrm{Cl}_{3}$ (syrupus) & . & . & $2 \mathrm{cc}$. & 0.5, \\
\hline $\mathrm{HCl}$ (concentrated) & - & . & . 2 cc. & . 1, \\
\hline Water . . & . & Use & $\begin{array}{l}80 \mathrm{cc} . \\
1 \mathrm{cc} \text {. per } 1000 \text {. }\end{array}$ & $\begin{array}{l}100 \text {. } \\
\text { Use } 3 \text { cc. per } 1000\end{array}$ \\
\hline
\end{tabular}

The proportionate amounts added to equal volumes of sea-water are :-

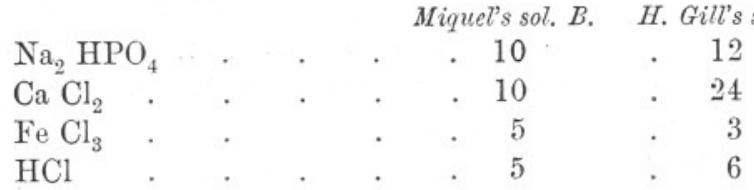


Since cultures can be obtained with no appreciable difference by using media prepared by adding either of these solutions, together with Miquel's solution A, to sea-water, a considerable latitude in the proportions of the salts present is tolerated.

We must now consider what is the róle of the various constituents in Miquel sea-water. The part played by any salt of a culture medium may be considered as being either, firstly, "nutritive," or secondly, "protective." * Under the first heading, any direct addition of food material must be included; under the second, any removal or neutralization of harmful substances, such as toxins and possibly bacteria, and any more remote effects, which, although influencing growth, do not directly enter into the metabolism of the plant.

Our experiments have proved that solution $\mathrm{A}$ can be reduced to a simple solution of potassium nitrate $\uparrow$ without detriment (cf. p. 427), and that the amount of growth is, within limits, roughly proportional to the amount of $\mathrm{KNO}_{3}$ added, as the following experiment shows :-

Inoculated from persistent culture of Thalassiosira decipiens.

A. Normal Miquel sea-water.

Growth as usual.

B. Ditto, but only one-half amount of sol. A.

Good growth at first, but exhausted sooner than A.

C. Ditto, but $2 \frac{1}{2}$ times amount of sol. A.

Was slower than either A or B at start, but afterwards was better than $\mathrm{A}$ or $\mathrm{B}$ and lasted longer.

D. Ditto, but five times amount of sol. A.

As $\mathrm{C}$, but in greater degree.

Considering the nature of the substance added, and its already wellknown action in plant metabolism, these results, coupled with the fact that exhausted cultures can often be regenerated by the simple addition of nitrates (see below, p. 444), are quite consistent with the assumption that sol. A is simply nutritive in action. The concentration of nitrates in natural sea-water is so low (Brandt, 47) that the amount available in a culture of untreated water very soon becomes completely exhausted, and it is this deficiency that sol. A probably corrects.

Considering now the action of sol. B, it must first be observed that increased concentration of nitrates alone will not explain the whole

* Loeb, The Dynamics of Living Matter (New York, 1906), p. 77.

$\dagger$ For the sake of convenience, the expression sol. A will be used throughout the rest of this paper to indicate a simple solution of potassium nitrate ( 5 per cent) and sol. B to indicate Miquel's phospho-ferricalcic solution (p.423). Unless otherwise stated, the amounts of each added to $1000 \mathrm{cc}$. sea-water will be normal, i.e. $2 \mathrm{cc}$. sol. A and $1 \mathrm{cc}$. sol. B.

NEW SERIES.-VOL. VIII. NO. 5. MARCH, 1910. 
action of Miquel's solutions, for no increase in growth is obtained when nitrates or sol. A only are added to sea-water. To illustrate this point an account of an actual experiment may be given :-

Inoculated with Thalassiosira decipiens.

A. Normal Miquel sea-water.

Good strong culture, in every way normal.

B. Outside water sterilized.

Small growth at first; very soon exhausted.

C. Ditto + sol. A.

No improvement over B.

D. Ditto + sol. B.

Fair growth. Great improvement on B and C, but exhausted considerably before $\mathrm{A}$.

E. Tank-water sterilized.

Appreciably better than B, but growth not large.

F. Ditto + sol. A.

Not even as good as E.

G. Ditto + sol. B.

Next best in series to $\mathrm{A}$; lasted longer than $\mathrm{D}$, and had better colour.

To generalize, no improved culture is obtained with sol. A alone, but a fair, though not very lasting, growth can result from using sol. B only.

The action of sol. B is to some extent obscured by the fact that, when this solution is added to the alkaline sea-water, a precipitate is formed. This precipitate is at first white, but, on heating or standing for some time, it becomes greenish yellow. We are indebted to Mr. D. J. Matthews for the following analyses.

Ten litres of normal Miquel sea-water were prepared, and the precipitate was collected on a filter paper washed and dried at $100^{\circ} \mathrm{C}$.

Weight of dry precipitate from 10 litres $=0.2949 \mathrm{grm}$.

$$
\begin{aligned}
& \text { Analysis of Dry Precipitate. }
\end{aligned}
$$

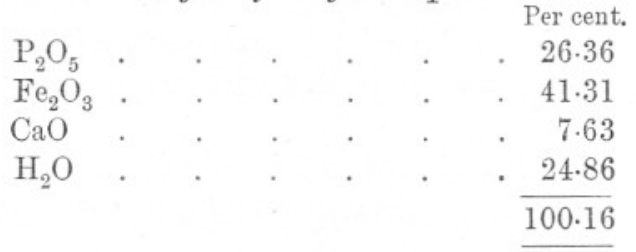

Or, the precipitate from 1 litre of normal Miquel sea-water contains:-

$$
\begin{aligned}
& \mathrm{P}_{2} \mathrm{O}_{5} \text {. . . . . . } .00777 \mathrm{grm} \text {. } \\
& \mathrm{Fe}_{2} \mathrm{O}_{3} \text {. . . . . . . } 01218 \text {," } \\
& \mathrm{CaO} \text {. . . . . .00225, , }
\end{aligned}
$$


An analysis of $1 \mathrm{cc}$. Miquel sol. B, the amount added to 1 litre Miquel sea-water, gave :-

$$
\begin{aligned}
& \mathrm{P}_{2} \mathrm{O}_{5} \text {. . . . . . .00825 grm. } \\
& \mathrm{Fe}_{2} \mathrm{O}_{3} \text {. . . . . . . } 0105 \text {, } \\
& \mathrm{CaO} \text {. . . . . . . . } 0145 \text {, }
\end{aligned}
$$

Comparing these figures, it seems probable that, when added to seawater, all the iron in sol. B is precipitated, and a certain amount also of the phosphate and calcium. The additive effect on the sea-water is therefore a slightly increased concentration of phosphate and calcium.

An analysis of a sample of tank-water for phosphorus, before and after treatment with sol. B (1 cc. per thousand), gave the following figures :-

$\begin{aligned} & \text { Tank-water } \\ & \text { Tank-water + sol. B } \\ & \text { (without precipitate) }\end{aligned} \quad . \quad .5$ mgrm. P per litre $=.00163$ grm. $\mathrm{P}_{2} 0_{5}$
(with $\quad . \quad, \quad, \quad,=.00488 \quad, \quad, \quad$,

It will be noticed that the figures from the different analyses do not agree very well. This is probably due to the fact that different samples were used for analyses in each case, and also to the fact that the solutions were made up in the ordinary way, without any special precautions, volumes, for instance, being measured in cylindrical glasses, pipettes, etc.

Cultures were tried in sea-water containing the normal amount of sol. A, plus the normal constituents of sol. B, less all the iron and less the amount of phosphate that would combine with the iron to form basic ferric phosphate $\left(\mathrm{P}_{2} \mathrm{O}_{5} 2 \mathrm{Fe}_{2} \mathrm{O}_{3} 12 \mathrm{H}_{2} \mathrm{O}\right)$. This solution should have very nearly the same chemical composition as normal Miquel sea-water from which the precipitate has been removed. Successful cultures could not, however, be obtained in it. Neither could cultures be grown in sea-water to which had been added the normal amount of sol. A and 1 mgrm. P (as sodium phosphate) per litre.

To ascertain the effects of the different constituents of sol. B, experiments were carried out with separate solutions of these constituents, each of the same strength as in Miquel's formula. Different combinations of these solutions were added, together with sol. A, to sterilized sea-water, and the resulting media were inoculated in the usual way. It was found necessary to repeat these experiments a great number of times, as the results obtained were rather contradictory. To illustrate the methods used, a list of the different media, and notes on the cultures obtained in them, are given below. These media were inoculated from cultures of Thalassiosira decipiens, and the 
cultures were kept under observation for at least four months. Series: were made as uniformly as possible, and controls in standard media were included in each. The strength of the various solutions used in these experiments was the same as in Miquel's formula.

A. Outside water + sol. A+sol. B (normal Miquel sea-water). First control.

B. Outside water + sol. $\mathrm{A}+\mathrm{Na}_{2} \mathrm{HPO}_{4}$ sol. $+\mathrm{FeCl}_{3}$ sol. $+\mathrm{CaCl}_{2}$ sol. Second control.

Good normal cultures were always obtained in these two controls.

C. Outside water + sol. $\mathrm{A}+\mathrm{Na}_{2} \mathrm{HPO}_{4}$ sol.

A very uncertain medium. Sometimes no growth has been recorded and at other times a fair growth results, but these cultures are never equal to normal Miquel.

D. Outside water + sol. $\mathrm{A}+\mathrm{FeCl}_{3}$ sol.

Occasionally a very small growth has been obtained, but at the best it is very poor.

E. Outside water + sol. $\mathrm{A}+\mathrm{CaCl}_{2}$ sol.

About equal to D.

F. Outside water + sol. $\mathrm{A}+\mathrm{Na}_{2} \mathrm{HPO}_{4}$ sol. $+\mathrm{FeCl}_{3}$ sol.

Uncertain as C ; no cultures have been obtained equal to the best in $\mathrm{C}$.

G. Outside water + sol. $\mathrm{A}+\mathrm{Na}_{2} \mathrm{HPO}_{4}$ sol. $+\mathrm{CaCl}_{2}$ sol.

Some cultures very nearly equal to the controls have been obtained. in this medium.

H. Outside water + sol. $\mathrm{A}+\mathrm{FeCl}_{3}$ sol. $+\mathrm{CaCl}_{2}$ sol.

Poor, about equal to D.

Analysing the above results, we see that-

(1) None of these modifications of sol. B give results equal to sol. B: itself.

(2) The best result is obtained from the combination of the phosphate and calcium chloride solutions.

(3) Of the solutions used singly the phosphate is the best, the iron and calcium chloride being about equal.

(4) The addition of $\mathrm{FeCl}_{3}$ to $\mathrm{Na}_{2} \mathrm{HPO}_{4}$, or the addition to $\mathrm{CaCl}_{2}$ to $\mathrm{FeCl}_{3}$, does not improve the medium to any extent.

Experiments were also made to determine whether the precipitate thrown down in sea-water by Miquel's sol. B, itself had any influence on culture media. A quantity of this precipitate was prepared, filtered off, and then added to outside sea-water + sol. A (nitrates). A small growth was obtained, which was a distinct improvement on the control without the precipitate, but exhaustion soon set in.

Further discussion of the mode of action of sol. B, and as to whether that action is purely nutritive, or partly nutritive and partly 
protective, is better postponed until a later section, after the action of animal charcoal and other substances has been considered (see p. 455).

Animal Charcoal and Peroxide of Hydrogen. The most successful culture medium for plankton diatoms, next to Miquel sea-water, is that prepared from animal charcoal (cf. p. 435). Animal-charcoal water gives at first almost as good cultures of plankton diatoms as Miquel sea-water, but the tendency to paleness and exhaustion appears much sooner. The best cultures were obtained in "Berkefeld water," that is, tank-water from the Plymouth Aquarium treated with powdered commercial animal charcoal and filtered through a Berkefeld filter. Tank-water as a basis for animal-charcoal water is very much better than outside water, probably on account of the higher concentration of nitrates, etc.

There is a very striking resemblance between the effect of animal charcoal and of Miquel's sol. B upon sea-water used for diatom cultures, and the growths obtained by using tank-water + sol. $\mathrm{B}$ and tank animal-charcoal water are very similar in character. If Miquel's sol. A is added to animal-charcoal water, there is a great improvement, both in the colour and quantity of diatom growth, and in the case of Thalassiosira decipiens the chains are long and well formed. With animal-charcoal water + sol. $B$, on the other hand, practically no growth was obtained.

It is possible that a certain amount of phosphate, and perhaps of calcium, from the animal charcoal, goes into solution and serves as a "nutritive" material for the diatoms. But we are inclined to think that its chief action is "protective," and due to its power of occluding gases, such gases being in a state of higher chemical activity than under normal conditions.*

As was explained in a previous section (p. 434), the possibility that the action of animal charcoal might have some sort of effect comparable to oxidation, led us to experiment with hydrogen peroxide. Fair growths of diatom could be obtained in sea-water prepared in the manner described, but they always showed a tendency to rather rapid exhaustion. As in the case of animal-charcoal water, tankwater proved a much better basis for treatment with $\mathrm{H}_{2} \mathrm{O}_{2}$ than outside water.

Reviving Exhausted Cultures. Several experiments were carried out with water from old, exhausted cultures. The sediment was filtered

* Against this view would seem to be the fact, that when powdered cocoanut charcoal, which has a still higher power of occluding gases, was used in the place of animal charcoal, very poor cultures were obtained.

the final result was, if anything, slightly better. As Miquel points out, these infusions must be made very dilute, otherwise growths of bacteria, moulds, etc., will completely swamp the diatoms. Karsten (7), in some interesting experiments, showed that Nitzschia palea (Kutz), W.Sm., could be made to alter completely its mode of nutrition. On placing this diatom in organic nutrient solutions, it lost all chloro- 
off, the filtrate was sterilized by heat, and then treated by various methods.

In one typical experiment the following was the result:-

Water from an exhausted culture of Skeletonema costatum in Miquel sea-water, reinoculated with the same diatom:-

A. Filtered and sterilized.

No growth obtained.

B. Ditto + sol. A (nitrates only).

Good culture, but did not last very long; further addition of nitrates made no improvement.

C. Ditto + sol. B.

No growth.

D. Ditto + sol. A+sol. B.

E. Ditto +an. char.

Very good growth, lasting considerably longer than B.

No growth.

Exhausted cultures in animal-charcoal water gave the same general results on treatment and reinoculation. In an old culture of Biddulphia mobiliensis in outside water + sol. $\mathrm{B}$ only, which was in a very exhausted condition (nine months old), the addition of $\mathrm{KNO}_{3}$ gave a very rapid regeneration, and the diatoms became of normal colour and form. This renewed growth, however, did not last very long, and a further addition of $\mathrm{KNO}_{3}$ did not give any result. The addition of sodium phosphate also failed to stimulate growth. The same rapid regeneration, on the addition of potassium nitrate, has been obtained with almost every medium, but a second attempt has always failed.

Silica. A very noticeable character of the true plankton species of marine diatom is, that their skeletons are very markedly less silicious than the great majority of other forms. Their valves are only feebly marked, if at all, and they will not stand the vigorous treatment of cleaning with acids and heat that is commonly used in the case of fresh-water diatoms. In cultural forms, this absence of silica is still more obvious, and no marking can usually be seen on even those forms which, under natural conditions, are the most silicious, e.g. Coscinodiscus excentricus. Deformed and distorted frustules are the rule in certain stages of growth in our cultures, and it is often very hard to make out more than the thinnest coating of silica. It is quite probable that this deformity can be accounted for simply by the absence of a strong silicious skeleton. As a rule, the more rapid the growth, the more teratological forms will be found. In untreated outside water little deformity will take place, but in normal Miquel, where very rapid growth takes place, the diatoms may assume almost 
any conceivable shape. The form of the frustules tends to come back to the normal again, when the culture is well started, and in old stages the majority will be perfectly formed, although small and pale. It was found that the addition of silica (in early experiments as fragments of potassium silicate) was, as far as could be judged, immaterial, which fact led to the conclusion that a sufficiency dissolved out from the glass flasks in which the cultures were kept. During rapid growth, it is possible that the silica does not dissolve out fast enough to supply the demand, although it is also possible that diatoms, during rapid division, cannot absorb silica and form a perfect skeleton, even when the supply is abundant. Richter (18) has proved the necessity of either $\mathrm{CaSi}_{2} \mathrm{O}_{5}$ or $\mathrm{K}_{2} \mathrm{Si}_{2} \mathrm{O}_{5}$ for the growth of Nitzschia palea, grown in pure cultures. We tried the addition of silica in various forms, and in one instance, in a culture of Coscinodiscus excentricus, to which a little precipitated calcium silicate had been added, the uniformity and markings of the valves were much more regular than in the control. The presence of a trace of pure, dialysed silica, also, in one experiment, gave an improved regularity of form, but the quantity or rapidity of growth did not seem to be affected. No sign of regeneration could be obtained in exhausted cultures by the addition of silica.

Organic Infusions.-Miquel recommends the use in culture media of infusions of organic substances such as bran, straw, diatom broth, etc., in addition to the saline solution. He does not make it quite clear if he ever dispensed with them at all. In his general directions, he certainly states that the addition of both saline and organic nutrient material is necessary. As would be expected from the general metabolism of plants, the saline constituents are sufficient for growth. At the same time, excellent cultures have been obtained from dilute organic infusions, both with and without the addition of Miquel's sols. A and B. About a square inch of Ulva was boiled in $600 \mathrm{cc}$. sea-water for half an hour, cooled and filtered. In this medium an excellent growth of Coscinodiscus excentricus in one case, and Biddulphia mobiliensis in another, was obtained, the growth lasting for some considerable time.

Infusions, made in the same way from a small piece of fresh fish, gave the same results, and although growth was rather slower at first, the final result was, if anything, slightly better. As Miquel points out, these infusions must be made very dilute, otherwise growths of bacteria, moulds, etc., will completely swamp the diatoms. Karsten (7), in some interesting experiments, showed that Nitzschia palea (Kutz), W.Sm., could be made to alter completely its mode of nutrition. On placing this diatom in organic nutrient solutions, it lost all chloro- 
phyll and became colourless, but in saline media the chlorophyll would not regenerate, and the nutrition change back from heterotrophic to autotrophic.*

Of course, with our infusions, it cannot be said that the diatoms were necessarily feeding on dissolved organic material, as some necessary, saline, nutritive materials could have dissolved out from the weed or fish. If the former is the case, it might explain the superiority of tank-water over outside water, since the tank-water must contain a much higher percentage of organic substances in solution. If an alternative mode of nutrition autotrophic or mixotrophic could be proved, especially in the case of the "bottom" forms of diatoms, a great many phenomena could be explained, but the evidence is as yet far too slight to warrant any such assumption.

Artificial Seca-water.-As we have explained in a previous section, the ideal aimed at, in this part of our work, has been to obtain strong growths of diatomaceae in purely artificially prepared solutions of simple salts. If this end could be satisfactorily attained, the difficulties due to the unknown and variable composition of natural seawater at once disappear. According to van 't Hoff (35) sea-water is a solution containing salts in the following molecular concentrations:-

$$
\mathrm{NaCl} 100 \cdot 0, \mathrm{KCl} 2 \cdot 2, \mathrm{MgCl}_{2} 7 \cdot 8, \mathrm{MgSO}_{4} 3 \cdot 8, \mathrm{CaCl}_{2} \mathrm{l} \cdot 0 \text { (varies). }
$$

Using these molecular concentrations, a sea-water of any desired salinity can be prepared. The chlorine content of average Atlantic water is about $\mathrm{Cl}=19 \cdot 4$, and samples of artificial sea-water were prepared with the same chlorine value, thus :-

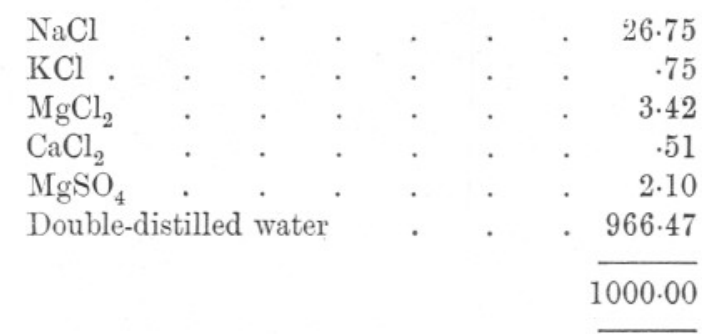

To make this solution comparable to natural sea-water, the "alkalinity" must be raised by the addition of an alkali such as $\mathrm{Na}_{2} \mathrm{CO}_{3}$. After the importance of "alkalinity" as a factor had come before our notice, $2 \cdot 4 \mathrm{cc}$. M/2 $\mathrm{Na}_{2} \mathrm{CO}_{3}$ was always added to the above solution in order to make the amount of base in equilibrium with $\mathrm{CO}_{2}$ equivalent to the usual $40 \mathrm{mgrm}$. $\mathrm{OH} \%$ (p. 450 ).

* Cf. Zumstein, Zur Morphologie u. Physiologie d. Euglena gracilis. Leipzig. 1899. 
The only success we attained with artificial sea-water as a basis for culture media was with four isolated cultures in one of our earlier experiments. Two of these were cultures of Coscinodiscus excentricus in artificial sea-water + Miquel's solutions A and B. The two cultures were identical except that one was in an ordinary Bohemian glass flask and the other in a "resistance glass" flask. No difference between these two could be seen. The growth obtained in both was in every way equal to normal Miquel sea-water, and is still fair, although over two years old. The other two successful cultures were growths of the same diatom in the same media, plus a small quantity of weed infusion, made by boiling up a small piece of Ulva in artificial seawater. These gave just as good results, but the addition of unknown factors from the weed detracts from their general interest. In spite of frequent attempts, over fifty in number, we have not been able to repeat this experiment, which may possibly be due to some accidental impurity in the salts or distilled water from which the successful media were prepared.

Alkalinity. Tornöe (43) and Dittmar (33) were the first to investigate the fact that sea-water showed on analysis an apparent excess of base over acid, which excess they termed "the alkalinity of sea-water." Dittmar defines the alkalinity of sea-water as "a measure of its potential carbonate of lime," but this definition, and his supposition that this excess of base combines directly with dissolved $\mathrm{CO}_{2}$ to form carbonates and, further, but only in very small proportion, bicarbonates, is liable to give a quite erroneous idea of the state of equilibrium actually occurring in the ocean. For, as Fox (3t) has shown, "sea-water reacts in situ very nearly neutral, and actually just slightly more acid than distilled water." This is due to the fact that sea-water always contains a considerable quantity of dissolved $\mathrm{CO}_{2}$.

If a salt solution with neutral reaction, that is containing $\mathrm{H}^{\bullet}$ and $\mathrm{OH}^{\prime}$ ions in concentrations equal to one another and the same as for pure water, be exposed to an atmosphere containing $\mathrm{CO}_{2}$, a definite amount, depending on pressure, temperature, and salinity, would go into solution. This $\mathrm{CO}_{2}$ would combine with water and form the very weak acid $\mathrm{H}_{2} \mathrm{CO}_{3}$, which would ionize with the formation of the free $\mathrm{H}^{\bullet}$ ions thus :-

$$
\begin{aligned}
& \mathrm{H}_{2} \mathrm{CO}_{3}{ }^{\prime} \rightleftarrows \mathrm{H}^{\bullet}+\mathrm{HCO}^{\prime} . \\
& \left(\mathrm{HCO}_{3}^{\prime} \rightleftarrows \mathrm{H}^{\bullet}+\mathrm{CO}_{3}^{\prime \prime}\right) .
\end{aligned}
$$

The second stage of dissociation is so small as to be negligible. The concentration of $\mathrm{H}^{*}$ being now increased, and $\mathrm{OH}^{\prime}$ decreased, the 
solution would have an acid reaction. The actual amount of $\mathrm{CO}_{2}$ thus dissolved would always be small; for instance, a salt solution of strength $\mathrm{Cl}=20 \cdot 00$ (average Atlantic water $\mathrm{Cl}=19 \cdot 4$ ) will at $10^{\circ} \mathrm{C}$. dissolve about .3 cc. $\mathrm{CO}_{2}$ per litre from an atmosphere containing $3 \% \mathrm{CO}_{2}$ (about normal). But the ocean is found to contain very much greater quantities than this, 60 cc., or two hundred times this amount, being a not unusual figure for the total $\mathrm{CO}_{2}$. The difference between this amount and the $\cdot 3$ cc. or so dissolved by the neutral salt solution, as above, is kept in equilibrium with the $3 \% \mathrm{CO}_{2}$ of the atmosphere, by the amount of "excess" base equivalent to the amount of acid neutralized when an acid such as $\mathrm{HCl}$ is added to sea-water in excess. If a solution identical with sea-water but absolutely free from $\mathrm{CO}_{2}$ (a practical chemical impossibility) could be obtained, then there would be present an excess of base over acid, and consequently an excess of $\mathrm{OH}^{\prime}$ ions over $\mathrm{H}^{*}$ ions, and an alkaline reaction. On exposing such a solution to the atmosphere, $\mathrm{CO}_{2}$ would go into solution, ionize, and the $\mathrm{H}^{*}$ ions thus set free would react with the $\mathrm{OH}^{\prime}$ ions, due to the excess base, to form water. And this reaction would continue to take place, on more $\mathrm{CO}_{2}$ dissolving, until all the excess $\mathrm{OH}^{\prime}$ ions were neutralized, at which point the solution would react neutral. Now, as before with the neutral salt solution, a further small amount of $\mathrm{CO}_{2}$ would go into solution, bringing the solution into equilibrium with the atmosphere, and the excess $\mathrm{H}^{\cdot}$ ions thus formed would give an acid reaction. The final result would be a solution exactly identical with natural sea-water. The total $\mathrm{CO}_{2}$ found in sea-water can be considered as existing in two parts: the larger part in equilibrium with free base, its amount depending on temperature, pressure, and alkalinity ; the smaller in equilibrium with the partial pressure of $\mathrm{CO}_{2}$ in the atmosphere, its amount depending on temperature, pressure, and salinity. Although sea-water in situ has an acid reaction, it still maintains the property of being able to neutralize a certain amount of any acid stronger than $\mathrm{H}_{2} \mathrm{CO}_{3}$, that is any acid which, on dissociation, forms a higher concentration of $\mathrm{H}^{*}$ ions; for the stronger acid will turn out the $\mathrm{H}_{2} \mathrm{CO}_{3}$ in equilibrium with the "excess base" and $\mathrm{CO}_{2}$ will be evolved.

In consideration of these points a less confusing definition of the "alkalinity of sea-water" would perhaps be a measure of its potential capability of neutralizing a strong acid* with the evolution of $\mathrm{CO}_{2}$. This can be conveniently expressed, as is usual, in mgrm. $\mathrm{OH}^{\circ} \%$.

Some of our earlier experiments seemed to show that "alkalinity" was a factor of considerable importance for the successful growth

\footnotetext{
* Such as $\mathrm{HCl}$, with a high degree of ionization.
} 
of cultures of plankton diatoms; so an attempt was made to analyse the various samples of water both before and after treatment as culture media. The method adopted was a modification of that used by Tornöe and Dittmar. Solutions of $\mathrm{NaOH}$ and $\mathrm{H}_{2} \mathrm{SO}_{4}$ of strength $\mathrm{N} / 50$, by intention, were made up and stored in 5-litre "aspirator" bottles. Two accurately graduated burettes standing side by side were connected to these by tubes, so that they could be readily filled by gravity. All air inlets to burettes and stock bottles were fitted with tubes of soda lime. A standard solution of $\mathrm{Na}_{2} \mathrm{CO}_{3}$ of exactly known alkalinity, approximately that of average sea-water $(40.00$ mgrm. $\mathrm{OH} \%$ ), was prepared by diluting down from a $\mathrm{N} /{ }_{10}$ solution, all operations being performed by weighing. These standards were stored in stoppered bottles of the fairly insoluble dark green glass, but those that had been kept for any length of time were not trusted, fresh standards being prepared. On analysis these standards agreed with one another to well within 1 mgrm. $\mathrm{OH}_{\%} \%$. The water used for diluting the standards was distilled water from the laboratory still, redistilled in all-glass apparatus with potassium bichromate and sulphuric acid.

When carrying out an analysis, equal volumes (about $100 \mathrm{cc}$.) of sample and standard were measured out into Jena glass Erlenmeyer flasks with a Knudsen automatic pipette. The specific gravity of each was determined by weighing in a 25 cc. pyknometer. Sample and standard were then titrated by running in acid from the burette and back titrating with alkali, using a $1 \%$ alcoholic solution of aurine as an indicator and keeping the liquid boiling. The acid to alkali equivalent was determined by titrating a pipetteful of double-distilled water in the same manner. The mean of at least four readings was always used. Let $\mathrm{N}$ and $\mathrm{n}$ be number of burette divisions of alkali equivalent to standard and sample respectively, and D and d their density at the time of pipetting out. Then if $\mathrm{A}$ is the alkalinity of the standard and $\mathrm{X}$ the required alkalinity of sample:-

$$
\mathrm{X}=\mathrm{A} \frac{\mathrm{Dn}}{\mathrm{Nd}}
$$

Since all operations were carried out at the same room temperature, no corrections for temperature are necessary.

In spite of the greatest care consistent results could not be obtained by this method of analysis. A sample analysed against the same standard would sometimes give results varying as much as $0.5 \mathrm{mgrm}$. and occasionally $1.0 \mathrm{mgrm}$. $\mathrm{OH} \%$. The work on indicators by Salm (42) and its application to this question has only recently come to our notice, and it is our intention to experiment on this in future research. 
The figures quoted below as the results of analyses have been rounded ofi as whole numbers, since their interest lies in their comparative rather than their absolute value, for convenience they are quoted as "alkalinities," although we are fully conscious that the methods used do not warrant this assumption, and that their actual chemical significance is still obscure.

The mean value for "outside water" was found to be fairly constant at $40.0 \mathrm{mgrm}$. $\mathrm{OH}^{\circ} \%$, which figure agrees with results obtained by others for average ocean water. Samples from the aquarium tanks never gave as high figures as this, the average being approximately $37.5 \mathrm{mgrm}$. $\mathrm{OH} \%$. From this it seems that the amount of base in equilibrium with $\mathrm{CO}_{2}$ in tank-water is appreciably less than in outside water. A series of thirteen samples taken from seven miles beyond the Eddystone to well inside the Cattewater (an inner tidal harbour near Plymouth) showed a gradual lowering of the alkalinity from the normal 40 , to $38 \mathrm{mgrm}$. $\mathrm{OH}_{\%} \%$ as the water became more estuarine and polluted.

The addition of Miquel's sol. B to sea-water was found, on analysis, to reduce the "alkalinity" by an amount equivalent to $10 \mathrm{mgrm}$. $\mathrm{OH}^{\circ} \%$ or more. The 1 cc. sol. B added to a litre of sea-water, in itself contains a certain amount of free acid, equivalent to less than $4 \mathrm{mgrm} . \mathrm{OH}^{\circ} \%$. But this reduction of alkalinity cannot be accounted for by the addition of free acid alone, because if only a quarter of the amount of sol. B is added, the alkalinity of the sample will be found to be, if anything, only very slightly higher. Also, if the various constituents of sol. $\mathrm{B}$ are added as separate solutions, thus obviating any addition of free acid, a reduction equivalent to about $6 \mathrm{mgrm}$. OH $\%$ is still obtained. The presence of ferric chloride in sol. B gives a possible explanation of this phenomenon. If a solution of ferric chloride is added to a solution of a soluble carbonate, a reaction, which can be expressed by the following equation, takes place :-

$$
3 \mathrm{R}_{2} \mathrm{CO}_{3} \text { Aq. }+\mathrm{Fe}_{2} \mathrm{Cl}_{6} \text { Aq. }=6 \mathrm{RCl} \text {.Aq. }+\mathrm{Fe}_{2} \mathrm{O}_{3} \mathrm{Aq} .+3 \mathrm{CO}_{2} .
$$

When the ferric chloride is added to sea-water, the final result will be that a certain amount of the "excess base" which was in equilibrium with $\mathrm{CO}_{2}$, will then be in equilibrium with the chlorine, available on the precipitation of hydrated ferric oxide, with a consequent liberation of $\mathrm{CO}_{2}$, and a reduction in "alkalinity" will, therefore, take place.

An analogy between the actions of Miquel's sol. B and animal charcoal can be seen in the fact that water treated with animal charcoal also shows a reduced "alkalinity," the amount being very variable in different samples. 
Sea-water treated with $\mathrm{H}_{2} \mathrm{O}_{2}$ also showed a lowering of the alkalinity, but in a much less degree when, as usual, minimal quantities were used.

Control experiments on double-distilled water, which had been treated with these substances, were tried, but great difficulty was found in obtaining an end point with the indicator. As far as could be judged, distilled water treated with sol. B (quantities as with seawater) showed a negative "alkalinity," equivalent to about $8 \mathrm{mgrm}$. $\mathrm{OH}_{\%}$, and in the case of animal charcoal a positive alkalinity equivalent to $6 \mathrm{mgrm}$. $\mathrm{OH} \%$, but the colour change was so slow that these results are only the roughest estimates. The possibility that the above results are due to some effect on the indicator, which entirely cloaks the true alkalinity, must always be taken into consideration.

Before any attempts at analysis had been made, the probability that considerable differences might be found in the alkalinity of the various media had presented itself. Improvement in the growth of diatom cultures was found to result from the purely empirical addition of $\mathrm{NaHCO}_{3}$, this result being most marked in normal Miquel sea-water, outside water + sol. B only, and Berkefeld water. No growth could be obtained in either tank-water or Miquel sea-water to which had been added $1 \mathrm{cc}$. $\mathrm{HCl}$ (pure, concentrated) per litre, but on again raising the alkalinity of the latter by the addition of $\mathrm{NaHCO}_{3}$ or $\mathrm{KOH}$ good normal growths resulted. Richter (18) and H. Gill (5), also, both state that a weak alkaline reaction is necessary for the growth of diatoms.

In our most recent experiments, all the media have been analysed for alkalinity, and those given in detail below illustrate the importance of determining this factor. Cultures of Thalassiosira decipiens were made in the following media :-

A. Tank-water. Control.

Poor growth, hardly normal. Later, good growth of minute forms, etc.

B. Tank-water treated with cold commercial animal charcoal and filtered. Very good growth indeed.

C. Tank-water treated with cold pure an. char. and filtered.

Very poor growth, comparable to A without minute forms.

D. Tank-water treated with pure an. char. as in C, but the an. char. was added red hot.

Fair growth, much superior to C, but not up to B.

The sample of pure an. char. used here had been previously found to give very poor results, and it was also quite contrary to our experience that any improvement in growth should be obtained by adding it hot. 
But if we examine the results of analyses of these media for alkalinity a probable explanation presents itself. The following figures are only comparative :-

$$
\begin{array}{lll}
\text { A }-38 \text { mgrm. } & \text { OH } \% & \text { (used as standard). } \\
\text { B-37 } \quad " \quad & \text { (higher than usual). } \\
\text { C-16 ", } & \text { (very low indeed). } \\
\text { D-34 " } & ,
\end{array}
$$

It will be seen that the amount of growth in each treated sample follows the alkalinity very closely.

Solutions of $\mathrm{Na}_{2} \mathrm{CO}_{3}, \mathrm{NaHCO}_{3}$ and $\mathrm{HCl}$ were made up, so that $4 \mathrm{cc}$. of any one contained an amount of acid or alkali equivalent to $10 \mathrm{mgrm}$. OH. From these a series of normal Miquel sea-waters of different alkalinities were prepared. Cultures of Thalassiosira decipiens were grown in these media.

A. Normal Miquel sea-water. Control. $\mathrm{A}=32 \cdot 7 \mathrm{mgrm} . \mathrm{OH} \%$. Perfectly normal growth.

B. Ditto +4 cc. $\mathrm{Na}_{2} \mathrm{CO}_{3}$ per litre. $\mathrm{A}=41 \cdot 7 \mathrm{mgrm} . \mathrm{OH}_{\%} / 0(=+9 \cdot 0)$.*

No difference between this culture and $\mathrm{A}$.

C. Ditto +8 cc. $\mathrm{Na}_{2} \mathrm{CO}_{3}$ per litre. $\mathrm{A}=50 \cdot 2 \mathrm{mgrm} . \mathrm{OH}_{\circ} / 0(=+17 \cdot 5)$.

Best culture in series in quality and quantity.

D Ditto +4 cc. $\mathrm{NaHCO}_{3}$ per litre. $\mathrm{A}=42 \cdot 4 \mathrm{mgrm} . \mathrm{OH} \%(=+9 \cdot 7)$.

Slightly better than control

E. Ditto +8 cc. $\mathrm{NaHCO}_{3}$ per litre. $\mathrm{A}=51.5 \mathrm{mgrm} . \mathrm{OH}_{\%} \%(=+18 \cdot 8)$. As D.

F. Ditto +4 cc. $\mathrm{HCl}$ per litre. $\mathrm{A}=22 \cdot 2 \mathrm{mgrm} . \mathrm{OH}^{\circ} \circ(=-10 \cdot 5)$.

Fair growth but never up to control, exhausted much sooner.

G. Ditto +8 cc. $\mathrm{HCl}$ per litre. $\mathrm{A}=11 \cdot 1 \mathrm{mgrm} . \mathrm{OH}_{\%} \%(=-21 \cdot 6)$.

Poorest in series.

Except in the cases where the alkalinity was lowered by the addition of $\mathrm{HCl}$, the results obtained from this series were not up to expectation. Nevertheless the majority showed a distinct improvement from increased "alkalinity" and in C, where the alkalinity had been raised $17.5 \mathrm{mgrm} . \mathrm{OH}^{\circ} \%$, this improvement was very marked.

Another point illustrated by cultural experiment is that in two samples of an. char. water, one with "outside" and the other with "tank-water" as a basis, the amount of growth in the latter considerably exceeded that in the former, and at the same time it was found that, with the tank-water, the alkalinity had not been reduced to the same extent as in the case of the outside water.

How far apparently anomalous results, which have so frequently

\footnotetext{
* Figures in parentheses are difference in alkalinity from control, in mgrm. $\mathrm{OH} \%$ 。
} 
occurred in our experimental work, could be explained by unforeseen changes in "alkalinity," can only be answered by future research.

Salinity.-The salinity (or amount of salts dissolved in a litre of sea-water) of the outside water used in these experiments only varied between small limits, $\mathrm{S}=34 \cdot \overline{\mathrm{c}}-35.5 \%$. The salinity of "tank-water" is also fairly constant, the average being about $\mathrm{S}=34.9 \%$; water is only pumped up into the reservoirs at high water, spring tides, and unless the salinity on analysis is well above $\mathrm{S}=34.5 \%$ no water is taken. Experiments to show what effect salinity pure and simple had on the growth of diatoms were undertaken. Samples of sea-water of various salinities were prepared by diluting down "outside water" with double-distilled water, and by concentrating "outside water" by slow evaporation. Two litres of "outside water" $\mathrm{S}=34.9$ were evaporated down to the bulk of one litre, giving a $50 \%$ * concentration. Miquel solutions 4 cc. A, 2 cc. B, were now added, and the solution was divided into ten culture vessels, $20 \mathrm{cc}$. in each. Doubledistilled water was added, 2 cc. to the first, 4 cc. to the second, $20 \mathrm{cc}$. to the last, so that a series of media were obtained, varying in salinity from normal to nearly $50 \%$ concentration, each containing the same amount of Miquel's nutrient solutions. These were inoculated from a mixed culture of Skeletonema costatum, Biddulphia mobiliensis, and Coscinodiscus excentricus. A good growth took place in all except the two with highest concentration. Of these two, the last remained practically sterile and the growth in the other was very poor. The limit of concentration, therefore, seems to lie between 35 and $40 \%$. In the same way series of lowered salinities were prepared, and cultures of the same diatoms were grown in these. Dilution up to $100 \%$ did not seem to make any difference at all in the quantity or quality of growth. In a series extending the dilution to $200 \%$ even in the cultures of lowest salinity, a fair quantity of growth took place. The range of salinities covered by the various series was $\mathrm{S}=12 \%$ to $\mathrm{S}=60 \%$ and within these limits no effect on growth could be observed, except in the very highest, where a distinct deterioration was noted.

An attempt to grow Coscinodiscus cxcentricus in tap water + Miquel's solutions was tried, and it was thought that some slight multiplication took place, although it was certainly not at all considerable. Inoculating a culture of normal Miquel sea-water from this after six weeks gave no growth.

Light. Of all the factors controlling the rate of growth of a culture, * i.e. from every $100 \mathrm{cc}$. sea-water $50 \mathrm{cc}$. $\mathrm{H}_{2} \mathrm{O}$ had been subtracted. 
light seems to be by far the most important. Without light a culture soon dies off completely, showing marked signs of malnutrition very soon after having been placed in the dark, the brown pigment being the first to go, and later the chlorophyll. A culture (Thalassiosira) placed in the dark for five months was found to be completely killed, the diatoms being quite colourless. In cultures kept in bulbous flasks or any spherical vessel, the strongest and earliest growth always takes place at the side of the vessel away from the source of light, where the light will be found to be concentrated owing to the lens effect of a sphere of water. By painting a flask black on the outside up to the water-line of the medium, a very marked diminution in the rate of growth was obtained. The total growth was not affected, but depends on the available quantity of food-stuffs present.

Experiments on the reaction of cultures to different rays of the spectrum, obtained by coloured glass, were tried, but no results obtained. Miquel obtained marked results with yellow light, but in our experience, with plankton diatoms, satisfactory cultures could not be obtained under these conditions.

Temperature. The highest temperature which diatoms and allied forms can stand was about uniform for all the species tested, and lay between $35^{\circ}-40^{\circ} \mathrm{C}$. Cultures of the following species, viz. Asterionella japonica, Nitzschia closterium, minute naviculoid diatom, Pleurococcus mucosus, Chilomonas sp., were slowly heated in a water bath, and at every rise of $5^{\circ} \mathrm{C}$. from $15^{\circ} \mathrm{C}$. to $45^{\circ} \mathrm{C}$., a few drops of the culture were pipetted out and a fresh flask inoculated. In all the flasks cultures were obtained where the heating process had not been carried above $35^{\circ} \mathrm{C}$., but none in those where the temperature had exceeded this.

In the earlier stages of experimentation the cultures of diatoms were kept in various places about the Laboratory, and so were under quite different temperature conditions. Those placed in the warmer situations, i.e. near hot-water pipes, as a rule gave the most satisfactory results. In all the later work the cultures have been kept in one room, and an attempt has been made to keep the temperature of this room as nearly as possible constant at $15^{\circ} \mathrm{C}$. A continuous record of its temperature has been kept by means of a recording thermograph, and no very great change of temperature has been noted. In a few isolated cases the temperature has dropped as low as $9^{\circ} \mathrm{C}$., and in hot weather has risen just above $20^{\circ} \mathrm{C}$., but these have only been for very short periods, the average temperature having kept remarkably constant. An apparatus in which flasks could be kept at 
different uniform temperatures from $10^{\circ}$ to $25^{\circ} \mathrm{C}$., by means of hot air, was used, but no really satisfactory result could be obtained. About $17^{\circ} \mathrm{C}$. seemed to give the maximum growth, and the cultures below this temperature were usually superior to those above.

General Conclusions. The general conclusions to be drawn from the experiments described in this section, which were made with a view to determining the conditions that underlie the successful culture of diatoms, may now be discussed. Although the experiments have involved the making of some 750 different cultures, our conclusions on many of the questions raised are still indefinite, and much further work will be necessary before a satisfactory answer can be given to them.

If we wish to obtain the maximum quantity of healthy growth of a plankton diatom, the diatom must first be obtained as free as possible from all other organisms, if not in a "pure" culture, at least in a "persistent" culture. All culture media should be sterilized either by heat or filtratiou, and the experiments should be conducted under sterile conditions. Starting with normal sea-water as the basis for the culture medium, it seems to be first necessary to raise the concentration of the nitrates, and possibly also of the phosphates, in solution. But this simple addition of nutrient materials will not in itself suffice. Some other action, such as that exerted by Miquel's sol. B, by animal charcoal, or by peroxide of hydrogen, seems to be imperative in nearly every case. The exact nature of this action we have not been able conclusively to determine. If the substance contained in sol. B were purely nutritive in character, we should expect that, when alterations in the amounts of the different ingredients were made, or when any one of the ingredients was omitted altogether, the differences in the quantity of growth would show a direct relation to the kind of modification introduced. But our usual experience has been that sol. B can be modified within certain limits, without producing any appreciable effect upon the resulting cultures, whilst if these limits are exceeded, there is an almost complete inhibition of growth. In supplying a necessary increase of phosphates, both Miquel's sol. B and animal charcoal may and probably do act as "nutritive" substances, but, since the addition of phosphates alone does not yield cultures comparable with those produced by either of these, and since, excepting phosphates, there is no possible common nutritive substance in their composition, we are led to conclude that, in addition to any nutritive effect, they must exert some other action. This view is supported by the results obtained by using $\mathrm{H}_{2} \mathrm{O}_{2}$. This substance cannot be directly "nutritive," although it may be so indirectly, by oxidizing into useful 
food-material substances which the diatoms are incapable of using in their metabolism, e.g. nitrites into nitrates. The absence of any increase in phosphates, when using $\mathrm{H}_{2} \mathrm{O}_{2}$, may possibly be the reason why better results were not obtained with this medium. The action which, in addition to any nutritive value, we must assume that sol. B, animal charcoal, and $\mathrm{H}_{2} \mathrm{O}_{2}$ can all effect, would appear to fall into the class of "protective" actions (p. 439). It is quite conceivable that, with different samples of sea-water, this "protective" action is not necessary in every case, and this would account for the anomalous results met with when using sea-water + nitrates + phosphates only, in which medium sometimes good cultures, but more often the reverse, are obtained. The effect of Miquel's sol. $\mathrm{B}$, animal charcoal, and $\mathrm{H}_{2} \mathrm{O}_{2}$ on the "alkalinity" of the sea-water, also points to some chemical change, which does not directly enter into the metabolism of the plants.

It may be pointed out that the action of such substances as finely powdered carbon, and ferric oxide precipitates, has been shown to produce a favourable effect on nutrient solutions used for the culture of certain higher plants, and it has been suggested that the beneficial action of these substances is the removal of toxic elements from the media (Breazeale, 3). Such removal of toxins would fall under our definition of "protective" action.

Of nutritive substances, other than those already mentioned, we have still to consider (1) silica and (2) dissolved oxygen and carbonic acid. Having regard to the conditions under which our cultures have been grown, i.e. in glass flasks, the question of silica does not seem to enter into the problems which we have discussed. A few words must, however, be said as to the dissolved gases. Whipple (62) and Baldwin (44) have drawn attention to the observed relations, which are found in natural waters, between algal growths and the amounts of dissolved oxygen and carbonic acid. That these factors are of great importance cannot be doubted, but in our cultures it seems reasonable to suppose that the conditions of saturation of these gases are the same in all, since series of cultures in standard media, such as Miquel sea-water or Berkefeld water, can be set up with the certainty that, if not every one, at least a very high percentage, will give normal results.

Of the purely physical factors, light is by far the most important. Within limits, the rate of growth in a suitable medium seems to depend directly on the intensity of the light (Whipple, 60). Absence of light, as would be expected, soon completely kills the diatoms.

Temperature also seems to affect the rate of growth to a certain extent, but for those temperatures at which we have experimented it does not appear to alter the quantity of growth. 
Salinity, apart from the quantities of available nutrient materials, can be varied within large limits without appreciable effect on the diatoms.

\section{MIXED CULTURES.}

In what has been said up to the present, we have been dealing with persistent cultures containing a single species of diatom, which are comparatively, if not entirely, free from admixture of other organisms. The study of cultures which contain a considerable mixture of organisms is not without interest.

A number of experiments have been made on the following lines. About 10,000 cc. of water, taken at some distance from shore, was placed in a tall bell-jar fitted with a "plunger," which keeps the water in constant movement. (Journ. Mar. Biol. Assoc., Vol. 5, p. 176). The water was treated with Miquel's solutions in normal proportions, and a considerable quantity of plankton taken with a fine-meshed net (150 meshes to the inch) was added, say, 10 or $20 \mathrm{cc}$. of a moderately rich sample of tow-netting. The experiments were made during the spring and summer months, and the general course of events has been the same, with a certain amount of difference in detail according to the nature of the plankton present at the time.

During the first two days the water often became cloudy, owing to the rapid multiplication of small flagellate infusoria, though this was not always the case. Plankton Copepods and other animals gradually died off, though some survived for as long as a week or ten days. The plankton diatoms, on the other hand, generally multiplied rapidly during the early days of the experiments, the first to become abundant in the body of the water being usually Skeletonema costatum, which at the end of a week might be so thick, that a number of chains could be seen in every drop of water examined with the microscope. Along with the Slieletonema were found other plankton diatoms, such as Landeria borealis, Chaetoceras (two or three species), Biddulphia mobiliensis, Ditylium Brightwellii, and in nearly every case Thalassiosira decipiens. These latter diatoms were present in moderate numbers only, when the Slieletonema was at its height; but as the Skeletonema died down they increased in quantity. At the same time Nitzschia closterium commenced to appear, both amongst the precipitate on the bottom of the jar, and in the general body of the water. Small green flagellates often began to get numerous also at this stage. The true plankton diatoms were at their height about a fortnight after the experiments were started. At this time a great many diatoms of all 
kinds were to be found amongst the precipitate at the bottom of the jar, Asterionella japonica and Coscinodiscus excentricus being often numerous here. During the course of the next week, however, Nitzschia clostcrium rapidly increased in quantity until, not only the sides of the jar were coated with it, but the whole mass of the water became thick and opaque. By this time the plankton diatoms had all disappeared, with the exception of those which may survive for a considerable period amongst the precipitate at the bottom of the jar. Bottom diatoms (Navicula, etc.) had begun to grow on the sides of the jar, and small green and brown algæ (Pleurococcus mucosus, Ectocarpus, etc.) also appeared. Infusoria (Euplotes and other smaller forms) then became numerous, and as the Nitzschica and bottom diatoms increased on the glass, large numbers of Amoebce made their appearance among them. The jars continued in this condition for many months, the algæ becoming more and more predominant.

From these experiments, as well as from instances of mixed cultures obtained in the course of our attempts to secure persistent cultures of single species of diatoms, it seems usual that, in a culture obtained by inoculating Miquel sea-water with plankton taken freshly from the sea, the true plankton diatoms are the first to develop in considerable numbers. Subsequently bottom diatoms and algæ of various kinds become abundant, and the true plankton forms die out.

A complete explanation of this sequence of events would probably be of a very complicated character, and we have practically no evidence from our experiments which bears very directly on the question. It would seem, however, that the early predominance of the plankton forms in the cultures would naturally follow from the fact that, in the plankton material used for inoculation, these plankton forms are numerous, whilst bottom diatoms and spores of algæ are rare. The subsequent very great predominance of such a species as Nitzschic closterium may be due simply to a very much more rapid growth rate, though it is difficult to avoid the impression that the organisms which finally take possession of the cultures, are in some way directly inimical to those which they supersede, not merely by robbing them of their food-supply, but perhaps, also, by the production of toxic substances. This suggestion does not, however, give an adequate explanation of the essential facts concerning these organisms. We have to consider two sets of species: (1) the true Plankton form ;, which flourish in the open sea and can be grown quite easily in the laboratory, provided the cultures remain pure; and (2) what we may call "aquarium" or " bottom forms," which under experimental conditions invariably take possession, when present in mixed cultures, whilst the plankton forms. 
are killed off. Why is it that, although species of the second class are always present in small numbers in plankton taken from the sea, they are there altogether outnumbered by the true Plankton forms, whereas under conditions such as those of our experiments they invariably succeed in gaining the upper hand? What are the factors which determine the difference in behaviour of these two sets of organisms in the sea and in the culture vessels? The whole question offers a very fruitful field for further experiment. The evidence at present available is so slight that further discussion of it here is not likely to be of much service.

The details of two experiments which we have made, bearing on the subject of mixed cultures, may, however, be recorded.

A flask, containing about 1000 cc. of sea-water treated with Miquel's solutions, was inoculated with approximately equal amounts of certain persistent cultures of diatoms, which we possessed at the time. The following diatoms were in this way introduced:-Chaetoceras constrictum, Biddulphia mobiliensis, Skeletonema costatum, Coscinodiscus excentricus, Streptotheca thamensis. The flagellate (Chilomonas sp.) was also introduced, since it was present in the culture of Coscinodiscus. The experiment was started on August 26th, 1907. On September 6th (11 days) Biddulphia, Coscinodiscus and Chaetoceras were increasing rapidly and were very healthy. Skeletonema was not so good, and no Streptotheca was fond.

On October 2nd (37 days) Biddulphia was numerous and healthy, Coscinodiscus was healthy but not so numerous. Skeletonema was poor, and Chaetoceras was not seen. Flagellates (Chilomonas) had become very numerous.

On October 31st (66 days) all the diatoms were in very poor condition, Coscinodiscus being slightly better than the others. The flagellates (Chilomonas) were extremely thick, giving the water a deep red colour.

Subsequently a small green alga (Pleurococcus mucosus) appeared, having probably been derived from the Coscinodiscus culture. This increased very greatly in quantity, whilst the flagellates became inconspicuous.

On July 28th, 1909 (1 year 11 months), some Coscinodiscus, which were still in a healthy condition, were seen in a sample examined from the flask. A great quantity of Pleurococcus, in a healthy condition, was also present, but no other organisms were noted. On this date a subculture was made from the flask in normal outside Miquel. The subculture gave a considerable growth of Skeletonema, the cells being, however, of a very abnormal character, and a good many normal and 
healthy Coscinodiscus were found in each sample examined. The whole culture was crowded with Chilomonas in a very active state, which gave the whole contents of the flask a deep red-brown colour. Up to August 24th, the green alga (Pleurococcus) had not become sufficiently abundant to be detected by the naked-eye appearance of the flask, though it could be seen in samples examined with the microscope.

In another experiment, a flask of Miquel sea-water was inoculated (May 4th, 1908) from two cultures, one containing the green alga (Pleurococcus mucosus) and the other Thalassiosira decipiens. At first both did well, and on May 20th (16 days) there was a very good cropboth of the diatom and the alga. Gradually, however, the alga became predominant, and on October 14th (163 days) only quite empty frustules of Thalassiosira could be found, whilst the growth of I'leurococcus was abundant and healthy. The only case where a diatom was observed to flourish in the presence of this green alga was in a culture of Nitzschia, a bottom form. In this case a very abundant growth of the diatom was obtained, but the Pleurococcus did not multiply to any extent, although it could always be found on microscopic examination.

\section{NOTES ON PARTICULAR SPECIES OF DIATOMS, ON THEIR METHODS OF REPRODUCTION, AND ON OTHER ALGA OCCURRING IN CULTURES.}

A list has been already given (p. 425) of those species of diatoms which we have obtained in "persistent" cultures. Of these, a species belonging to the genus Thalassiosira has been used for experimental work in the great majority of cases. We are not quite certain as to the identity of the species, but since it most resembles 'T. decipiens, Grun., we have called it by that name, although it does not exactly conform to the published descriptions of that form. The most characteristic feature of this particular species is the eccentric markings on the valves, which are also seen on the valves of the diatom Coscinodiscus excentricus, Ehr., and, as is typical of the genus, the frustules are united into chains by a delicate filament. Jörgensen (50, p. 96) describes the valves as "decidedly convex," Gran (49) as "flat," and both agree that there are marginal spines and a single asymmetrical spine. Our cultural forms are united together by a filament into chains, some of which are made up of five hundred cells and more, but the distance between each is considerably smaller than that figured by Gran. The valves are quite flat and the marginal spines are often 
present, although this is not always the case. The odd asymmetrical apiculus can nearly always be seen. The eccentric markings have only been observed in a few isolated cases, and are then usually very indistinct. In one culture these markings on the valves were very distinct, and were also easily seen on the megafrustules (cf. below) which developed in it, but in none of the several generations of cultures started from this one have we been able to find any traces of marking at all. The genus seems to be in considerable confusion, and it is probable that the conflicting descriptions given by different observers are due to variations in what is really one species.

Persistent cultures of Coscinodiscus excentricus, Ehr., have also been obtained, and it is interesting to note that this diatom sometimes forms chains, but they are rather exceptional. These chains are never as long as those commonly found with Thalassiosira, two or four cells only being the rule. The filament joining the valves is also finer and more easily broken. The two species are quite distinct, and cultures of them can be discriminated by a practised eye.

Two species of the genus Biddulphia are commonly met with in our cultures, namely Biddulphia mobiliensis (Bail.), Grun., and Biddulphia regia, M. Schultze. These two forms are generally regarded as one species, but Ostenfeld (54) has recently shown that they are really distinct. We have obtained persistent cultures of both forms from several different samples of plankton, and the two species are easily recognizable, never merging into one another. When Petri dishes, inoculated from plankton (see p. 425), contain both species, the colonies can be easily distinguished with a small hand lens.

The most generally accepted theory of the reproduction of the diatomaceæ is briefly that the cells divide by simple fission, but on account of the rigid character of the cell walls each division necessitates a decrease in size of the new valve, since this must always be formed inside the old valve. So the frustules gradually get smaller and smaller as multiplication proceeds, thus necessitating some process by which the original size can be re-established. This takes place by the formation of what are known as auxospores, which ultimately form megafrustules, and these in turn multiply by division until the minimum limit of size has again been reached. There are also several special processes of reproduction, but no occurrence of any of these has been noted in our work (cf. Miquel, 14).

The diatoms in our cultures multiply by simple fission, and although there is, in nearly every case, a considerable diminution in size when compared with specimens from the plankton, this diminution soon 
seems to reach a limit, where further decrease does not take place. In chains of Thalassiosira, several hundred cells in length, no difference in size between individuals could be made out. Auxospores are commonly formed with every species, but only in the cultures of Coscinodiscus and Thalassiosira have megafrustules been found, and in these they are very exceptional. These megafrustules seem to divide once or twice and then die or form new auxospores. What exactly is the fate of these auxospores, which are often exceedingly numerous, we have not been able to make out. It seems that cultural conditions are not favourable to this mode of reproduction, and that the auxospores do not further the multiplication of the diatom at all. If this were not the case, stages of the formation of auxospores into frustules must have been seen in some at least of the very numerous samples examined. As it is, what has been said to take place is, that the cell contents expand and force apart the valves of the diatom and emerge as a spherical body about three or four times the diameter of the parent cell. The chromatophores and diatomin then collect to one side, forming a compact cap against the cell wall. Beyond this point no stages have been found, except in the case of the few cultures where megafrustules were formed. In these the chromatophores, etc., gradually formed into the shape of the diatom (Coscinodiscus), the silicious coat with plain eccentric markings was easily seen inside the spore, and lastly, the cell wall of the spore burst, leaving the megafrustule free. The megafrustule was measured and found to have a diameter three times that of the parent cell.

In the case of the diatom we have very largely used for feeding larvæ, etc., namely Nitzschia closterium, forma minutissima, a great number of cultures have been made, all originating from the single drop from which the first persistent culture was obtained. The total amount of growth in all the various cultures has been enormous, and the number of generations must be quite inconceivable. No diminution in size has, however, been appreciable, and no sign of any method of re-establishment of size has been seen, although these cultures have been under constant observation for over two years. This seems to prove that the theory of gradual decrease in size with successive generations cannot be generally applied.

The following experiment on the rate of multiplication of Thalassiosira in normal Miquel sea-water was carried out. A single drop from a fresh and vigorous culture was kept under a microscope as a hanging-drop preparation in a moist chamber. The number of diatoms in this drop was counted from time to time, and the results are given in the following table:- 


\begin{tabular}{|c|c|c|c|c|c|c|}
\hline Day. & & & $\begin{array}{l}\text { mber of } \\
\text { ustules. }\end{array}$ & & & $\begin{array}{l}\text { Geometric } \\
\text { progression. }\end{array}$ \\
\hline 11 th & . & . & 59 & . & . & 63 \\
\hline 14 th & & . & 62 & . & . & 68 \\
\hline 19 th & . & . & 85 & . & . & 85 \\
\hline 27 th & . & . & 140 & . & . & 120 \\
\hline 34 th & . & . & 170 & . & . & 160 \\
\hline 41st & . & . & 190 & . & . & 220 \\
\hline
\end{tabular}

The curve obtained by plotting the number of diatoms against the number of days approximates the curve of an ordinary geometric progression, where the ratio is two and the periods are equal to sixteen days. To show this the figures read off from the curve at the same intervals as the diatoms are appended in the table. From this it will be seen that, after a start had been made and before exhaustion set in, the numbers obtained agree fairly closely with the assumption that every diatom divided once in a period of sixteen days. Probably in normal cultural conditions the rate of multiplication greatly exceeds this figure on account of better lighting, etc. (cp. Miquel, 12).

Besides diatoms, many other organisms appear in these cultures. We are indebted to Prof. G. S. West for the identification of a form of unicellular alga, which is very common and difficult to avoid when attempting to obtain persistent cultures of the Diatomacec, namely Pleurococcus mucosus (Kutz.), Rabenh. This small green alga, if once introduced into a culture of a plankton diatom, will soon multiply at the expense of the latter with its ultimate extinction. It is very hardy and cultures of it in almost every medium seem to last indefinitely. Multiplication beyond a certain point probably does not occur, but the cells retain their colour and normal shape and will start active reproduction if suitable nutrient material is provided.

In cultures inoculated from plankton many other forms of unicellular and filamentous algæ thrive. Several species belonging to the classes Rhodophycea and Myxophycee commonly occur, but we have not been able to identify them. The most usual filamentous forms of Chlorophycew are Enteromorpha, Vaucheria, Rhizoclonium, etc. It is interesting to note that it was the unintentional appearance of young plants of Laminaiia digitata in some of our Petri dishes that led Mr. Drew (4) to cultivate this alga in Miquel sea-water and so discover its early life history. Cultivations of marine algæ by these methods would without doubt yield manẙ new species, and would also provide rich material for the study of their modes of reproduction.

Many forms of flagellates live either together with diatoms or alone. Among these is an unidentified species of Chilomonas which we have obtained in persistent culture. It multiplies very rapidly, colouring 
the whole medium a deep red-brown. It flourishes in Miquel sea-water, and its nutrition is evidently autotrophic. In one culture in Miquel sea-water inoculated with plankton a number of Coccospheres developed, probably Coccosphara atlantica, Ostenf. Other flagellates and ciliated infusoria are very commonly met with, such as Bodo, Euplotes, Euglena, etc., which all seem to depend on the diatoms or other vegetable organisms for their food material.

\section{THE REARING OF MARINE LARVA.}

In the rearing of pelagic larval forms of marine animals, * the principle which we have followed has been to introduce into pure, sterile sea-water the larvæ to be reared, together with a pure culture of a suitable food. As far as practicable all other organisms have been excluded from the rearing vessels. It should be added that the food used in all successful experiments has been of a vegetable nature, and has continued to grow actively in the vessels. This is important from the point of view of oxygen supply. Under the above conditions, or rather under the nearest approach to them at which we have been able to arrive, no change of water has been found necessary.

Methods.-It will, perhaps, best make the matter plain if we first of all describe the actual procedure which we now follow in the case of such an animal as Echinus esculentus or E. acutus. The water to be used is first of all prepared by treating water from the aquarium tanks with powdered animal charcoal, filtering it through a Berkefeld filter (p. 431), and collecting it in sterilized glass vessels. All instruments and pipettes are sterilized by baking in an oven, and a fresh sterile pipette is used for each operation during the progress of the work. Specimens of Echinus are then opened until a perfectly ripe female has been found, that is to say, one in which the eggs separate quite freely, when a portion of the ovary is shaken in sea-water.

Pieces of ovary taken from a little below the exposed surface are then placed in sterile sea-water in a shallow glass dish and shaken with forceps in order to get the eggs well separated, or a number of eggs from the centre of the ovary are drawn up with a pipette and placed in the water. A very small quantity of active sperm from a ripe male is then added, very little being sufficient to fertilize a large number of eggs. Excess of sperm should be avoided owing to its liability to putrefy. After an interval of ten or fifteen minutes the water containing the eggs is filtered through bolting silk of 100 meshes per inch, which just allows single eggs to pass through, whilst keeping

\footnotetext{
* See Bibliography; especially Grave (26), MacBride (28-30), Doncaster (25), ete.
} 
back clusters of eggs or other large material. The filtrate is divided amongst a number of tall narrow beakers containing sterile seawater, and the beakers, after being covered with a glass plate, are placed where the temperature will be uniform and not rise much above $15^{\circ} \mathrm{C}$. In the course of twenty-four hours the healthy larvæ will swim up to the surface and can be easily seen and removed from vessels of this shape. They are transferred by means of sterile pipettes to jars* of sterile sea-water, about fifty to seventy larvæ being put in each jar of 2000 c.c. sea-water. At the same time, a good pipetteful of a pure culture of diatom is added to each jar. The small diatom Nitzschia closterium, forma minutissima, we have found most useful, as its size is suitable, and it grows well in animal-charcoal tank-water, floating throughout the body of the water, and so being in intimate admixture with the larvæ. The jars are placed in a moderate light and at as even a temperature as possible. $\uparrow$ No further attention is necessary until the larvæ have metamorphosed. The metamorphosis takes place in from six to nine weeks after fertilization. Larvæ may be taken out from time to time and examined to see if they are feeding well. If the diatoms do not grow sufficiently rapidly in the jar, more should be added from the culture flasks. We are more often troubled, however, towards the end of an experiment by an excessive abundance of diatoms. In this case the jar may either be put in a darker place or some of the water may be drawn off and replaced by a fresh supply of sterile sea-water. Care should be taken to have a sufficient supply of food at the beginning of the experiment, so that the larvæ may be able to feed as soon as they are ready for food.

The method just described can be modified in various ways without detriment to the result. Sufficient sterilization of the water may be effected by heating to $70^{\circ} \mathrm{C}$. for fifteen minutes, after which it should be aerated by violent shaking; "outside" water may be used instead of "tank-water," and may be treated with Miquel's solutions in the ordinary way, to ensure a satisfactory growth of the food-diatom.

With regard to the food organisms, we have tried to obtain as large a variety of these in pure culture as possible, and then to make trial of a number of them with each batch of larvæ on which we have experimented. If no suitable pure cultures are available, success can sometimes be obtained by adding a few drops of tow-netting, collected with a fine-meshed net (180 meshes per inch), directly to the treated

* The vessels we use are ordinary green glass sweet-jars, having a capacity of about 2000 c.c., which are kept covered with the glass stoppers provided with such jars, from which the cork band has been removed.

† In hot weather we often stand the jars in one of the tanks of circulating aquarium water, which maintains them at a very uniform temperature. 
sterile water containing the larvæ. In this case one depends on the chance of a suitable food organism growing in the vessel unaccompanied by any destructive organism. On several occasions a satisfactory result has been reached by proceeding in this way, and the method is generally worth a trial, seeing that the number of larvæ obtainable from an ordinary fertilization is very large, and many different experiments are easily made with them.

We will now give details of some of the results obtained by making use of the methods described, or of their unodifications.

Echinus acutus.-The first successful experiment was made with this species. Eggs fertilized on June 13th, 1905, produced healthy larvæ, 50 to 75 of which were placed, three days later, in a glass jar containing 2000 c.c. of outside sea-water, filtered through animal charcoal, to which modified Miquel solutions were added. They were fed on a diatom culture, containing a small species of Chaetocerces, which did not form chains, a small diatom probably belonging to the genus Melosira, a small Naviculoid diatom, two minute flagellates, and a small green organism, probably one of the Pleurococcacece. The vessel stood in a shallow tank, through which a stream of aquarium water was flowing, and the temperature was fairly constant at $15^{\circ}$ or $16^{\circ} \mathrm{C}$., though there is one record of $19^{\circ} \mathrm{C}$. at the end of July. The first two young Echinus were seen on July 25th, 42 days after fertilization, and on August 1st 20 were counted. On August 5th (the 53rd day) a careful search through the jar gave 21 young Echinus of normal size attached to the glass, 6 minute but fully formed Echinus, about 23 still in the Pluteus stage, roughly half of which were well advanced. On August 16th some of the water, which had not been changed since the beginning of the experiment, was replaced by "outside" water. On October 5th (16 weeks after fertilization) 12 Echinus were still alive. Some pieces of red seaweed were placed in the jar, upon which the Echinus fixed themselves and fed. Several of these specimens lived for over a year, but sufficient attention was not given to finding suitable food for them after the metamorphosis, so that they did not grow very large.

Echinus esculentus.-Three successful experiments have been made with $E$. esculentus. In the first (eggs fertilized April 5th, 1907) “outside" water treated with animal charcoal and filtered through filtercloth, but not otherwise sterilized, was used. A number of jars of 2000 c.c. capacity containing larvæ were set up, and, to the most of these, various diatom cultures then in our possession were added, none of which, however, gave a satisfactory result. In two jars, on the 
other hand, to which no culture was added, there was considerable growth of diatoms and of a flagellate, upon which the Plutei fed. The first young Echinus were recorded in both jars on June 8th (64 days), but may have been present a few days earlier. Eventually from 30 to 40 metamorphosed in one jar and about 12 in the other. The temperature varied from $10.5^{\circ}$ C. to $12.5^{\circ} \mathrm{C}$.

In the second experiment (eggs fertilized June 8th, 1908), made with similar water, the larvæ were fed on a pure culture of Nitzschio closterium, var., and six had completely metamorphosed on July 26th (48 days after fertilization), two more subsequently coming through. The temperature was generally $15^{\circ}$ to $16^{\circ}$ or $17^{\circ} \mathrm{C}$.

In the third experiment (eggs fertilized March 29th, 1909) aquarium tank-water treated with animal charcoal and then filtered through a Berkefeld filter was used. Plutei, fed with a pure culture of a small flagellate (probably Chilomonas sp.) grew satisfactorily, and eight young Echinus were found on June 5th (68 days after fertilization), which had probably metamorphosed some days earlier. Two other jars in which Nitzschic closterium, var., was used as food, were not successful, probably because the growth of diatoms became too thick towards the end of the experiment.

Echinus miliaris. In the first experiment with this species animalcharcoal Berkefeld water was used, each jar containing as usual 2000 c.c. In one jar the Plutei, from eggs fertilized on August 27th, 1907, were fed on a pure culture of Nitzschia closterium, var. On October 4th, i.e. thirty-eight days after fertilization, one Echinus had just metamorphosed. On October 29th about a dozen healthy-looking Echini were climbing about the jar, and many were still in a healthy condition on January 8th, 1908 . Temperatures: September, $15^{\circ}$ to $19^{\circ}$ C., October, $16^{\circ}$ dropping to $13^{\circ}$ towards end, November, $12^{\circ}$ to $11^{\circ} \mathrm{C}$., December, $15^{\circ}$ to $10^{\circ} \mathrm{C}$.

To another jar containing larvæ from the same batch a few drops of fresh Plankton were added as food. The Plutei in this case fed on flagellates and Nitzschia which grew in the jar, and several metamorphosed.

In a second experiment with eggs fertilized on September 13th, 1907, the larvæ were fed with Nitzschia closterium, but although there were a. few well-advanced Plutei still living on January Sth, 1908, none completed the metamorphosis.

Cucumaria saxicola. A female Cucumaria, one of a number in a dish containing "outside" water, laid eggs, which were fertilized, and segmented on May 12th, 1906. A number of these were placed in a 
flask in 800 c.c. of "outside" water, which had been sterilized by heating and then treated with animal charcoal and filtered. About 1 c.c. of fine plankton, containing diatoms, was added to the flask on May 12th. On May 25th some of the water was poured off and a new supply added. As the amount of food seemed small, some culture of a green alga (Pleurococcus mucosus (Kutz.), Rabenh.) was added, and this continued to grow well in the flask. The larvæ continued healthy and formed young Cucumaria, of which many were still alive on July 25th, 1907 , i.e. fourteen months after fertilization. Some of the water was changed in this flask on May 30th, 1906, June 18th, 1906, September 15th, 1906, and July 25th, 1907. Although many of these Cucumaria remained quite healthy they did not grow to any great size. Probably the food which was suitable to the larvæ and early stages, ought to have been changed as the animals grew older.

Pomatoceros triqueter. The larve of Pomatoceros are perhaps the easiest to rear, and give the most certain results of any with which we have experimented. They do well on the minute variety of Nitzschia closterium, but will feed upon almost any small diatom. Since the adults live in calcareous tubes attached to stones, and the tubes have to be broken open before the eggs can be obtained, it is not easy to get the latter free from infection of other organisms. If, therefore, the eggs are fertilized and placed in sterilized animal-charcoal water with only moderate precautions, sufficient growth of diatoms or other organisms will generally take place in the jar to feed the larvæ and bring them to the adult state. When once fixed to the glass the worms are very hardy and healthy, and a stream of ordinary aquarium water can be run through the jar. They then grow rapidly and attain a size equal to any found on the shore. The following experiment may be given in detail to illustrate the time occupied in development. On August 29th, 1907, eggs of Pomatoceros triqueter were fertilized in animal-charcoal Berkefeld water, and some pure culture of Nitzschia closterium, var., added. The larvæ fed well, and on October 1st (i.e. thirty-three days after fertilization) a great number had fixed on the sides of the jar and made quite normal tubes. A constant stream of the ordinary aquarium water was then allowed to run through the jar, and the worms continued to grow and flourish, reaching a large size, and are still alive and healthy (November, 1909). A similar result was obtained from the same batch of eggs by feeding on a pure culture of a flagellate infusorian. Temperatures during these two experiments were between $15^{\circ} \mathrm{C}$. and $19^{\circ} \mathrm{C}$.

Chatopterus variopedatus. Four experiments were made with this 
species. The food which gave most promise of success was the diatom Nitzschia closterium, var. Larvæ from eggs fertilized on July 20th, 1908 , fed on this material lived until October 30th, and reached an advanced stage. They did not, however, adopt the adult habit and form tubes. Two larvæ were also reared to an advanced stage by using flagellates and, in later stages, the diatom Skeletonema costatum as food.

Sabellaria alveolata. One experiment only was made with this species on eggs fertilized on July 19th, 1908. The eggs were fertilized in "outside" water and the larvæ subsequently transferred to jars containing animal-charcoal Berkefeld aquarium water. They were fed on a pure culture of Nitzschia closterium, var., and kept healthy and active and developed well until nearly the end of October, when, simultaneously with a sudden drop in the temperature from $15^{\circ}$ and $16^{\circ} \mathrm{C}$. to $12^{\circ}$ and $9^{\circ} \mathrm{C}$., they sank to the bottom of the vessel and in about three days were all dead. Temperatures:-During July and August, the temperature kept fairly constant at about $17^{\circ} \mathrm{C}$., with a range from $15^{\circ}$ to $19^{\circ} \mathrm{C}$. During September it was generally about $15^{\circ} \mathrm{C}$., and continued at about this level until the fall in the middle of October.

Archidoristuberculata. A good many trials have been made to rear the larvæ of nudibranchiate molluses, but up to the present not much success has been achieved. The best experiment was one made with larvæ of Archidoris tuberculata. A number of veligers of this species hatched out on May 8th, 1908, from some spawn, which had just been collected from the shore. Some of these were put in a flask containing 1000 c.c. of sterilized animal-charcoal water and about 1 c.c. of fine plankton was added. On May 14th a few veligers were transferred to another flask of sterilized animal-charcoal water and some pure culture of the green alga, Pleurococcus mucosus, was added. Whereas the larvæ in the original flask did not live long, those provided with the green alga fed well and developed for some time. A number of them were active and vigorous on July 4th, i.e. 51 days after hatching, and several were still swimming at the end of July. On August 15th none could be seen moving, but two of those which lay on the bottom, when examined with the microscope, showed no sign of decomposition. The animal was retracted in the shell, but the tissue looked healthy, and the eye-spots and otoliths could be seen. The growth in the flask seemed to be a quite pure culture of Pleurococcus. Larvæ were examined again on September 14th, and appeared much as in August, the tissue still showing no sign of dis- 
integration. The flask was not again examined microscopically until July 25th of the following year (1907). No sign of the larvæ could then be seen, but the culture of Pleurococcus remained pure and healthy.

Subsequent experiments were made with spawn, which was deposited by the females in confinement. Although the spawn hatched and gave apparently healthy larvæ, these did not live for more than a few days.

Calanus finmarchicus. A single experiment is perhaps worth recording, as showing that it ought to be possible to rear this species without great difficulty. On August 8th, 1905, to a flask containing 1000 c.c. of outside water (unsterilized) there was added $\frac{1}{2}$ c.c. of Miquel's solution B and $\frac{1}{2}$ c.c. of a 1.5 per cent solution of anhydrous sodium carbonate. A few Calanus finmarchicus and some decapod Zoeas were put in, together with a quantity of a culture containing mixed diatoms. On September 8th all the Zoeas were dead, but three Calanus were alive, and Nitzschia and a number of bottom diatoms were very plentiful. On September 17th the three large Calanus were alive and vigorous, and a considerable number of Nauplii were seen in the flask. By September 22nd two of the Nauplii had developed into young Calanus. These, however, did not live for more than a week or ten days, and the adults also died. The flask was abandoned on November 13 th, the water in. it not having been changed since the commencement of the experiment.

Echinus hybrid. A successful experiment on crossing E. esculentus and $E$. acutus was carried out by Mr. W. De Morgan, who was working at the Plymouth Laboratory. We provided him with treated water and diatom cultures for food, and he followed our methods. We are indebted to him for allowing us to publish these results. Some eggs from a ripe E. esculentus were fertilized by active sperm from $E$. acutus in sterilized water on March 29th, 1909. Healthy larvæ were obtained and were transferred two days later to tankwater, which had been treated with animal charcoal and filtered through a Berkefeld filter. A culture of Nitzschia closterium, var., was added as food, and the larvæ developed rapidly, feeding well. Several were completely metamorphosed on May 7th, or thirty-nine days after fertilization. In all thirty young hybrids were obtained, and a number of these are still alive and feeding on red weeds.

Sacculina carcini. Mr. Geoffrey Smith has recorded the fact (Quart. Journ. Micr. Sci, LI, 1907, p. 625) that he was able to rear the larvæ of Sacculina up to the Cypris stage, when they attached themselves to 
their host, Carcinus maenas. These larvæ were kept in aquarium tank-water treated with animal charcoal and filtered through a Berkefeld filter. In this case the question of food did not arise, as the larvæ do not feed after hatching. It must be noted, however, that these larvæ had previously been reared by Müller and by Delage.

Summary of Method for Rearing Larve. We have found that the best results in rearing marine larvæ have been attained by taking the following precautions :-

1. The eggs of the female selected must be really ripe, and the spermatozoa of the male active.

2. The smallest quantity of sperm necessary to fertilize the eggs should be used.

3. Sterile sea-water, treated in such a way that diatoms, etc., will grow well in it, should be used. No frequent change of water is then necessary.

4. All dishes, jars, instruments, and pipettes should be carefully sterilized before use. Every possible effort should be made to prevent the introduction into the rearing-jars of any organisms other than the larvæ to be reared, and organisms on which they feed. The jars should be covered with loosely fitting glass covers.

5. The eggs after fertilization must be separated from all foreign matter, pieces of ovary, or testis, etc. As soon as the larvæ swim up they should be pipetted off into fresh vessels of treated water, so as to leave behind any unsegmented eggs, etc.

6. The food organisms should be small in size, so that the larvæ can draw them into the mouth by ciliary currents. The food should distribute itself through the body of the liquid and not settle too readily on the bottom of the vessel. (This is one of the great advantages of the diatom Nitzschia closterium, forma minutissima.)

7. The food should be abundant early, so that the larvæ may commence feeding as soon as they are able to do so. The food, however, must not be allowed to get excessively thick in the water. It can be kept down by diminishing the light or by changing some of the water.

8. The temperature should be kept as constant as possible. Within limits, the actual degree of temperature is not so important as the avoidance of rapid change of temperature.

9. A good north light, not exposed to direct sunlight, is most suitable for the rearing-jars.

NEW SERIEs.-voL. viri. No. 5. MARCH, 1910. 
10. In determining the amount of water to be used in any particular vessel, regard must be had to the amount of water surface exposed to the air, which should be large in proportion to the volume of the water.

11. A change of food is generally required after the metamorphosis of the larvæ.

\section{BIBLIOGRAPHY.}

\section{Cultures.}

1. Beijerinck, M. W.-Das Assimilationsprodukt der Kolensäure in den Chromatophoren der Diatomeen. Rec. Trav. Bot. Neerland, I, 1904, p. 28.

2. Benecke, W.-Über farblose Diatomeen der Kieler Föhrde. Pringsh. Jahrl., $\mathrm{xxxv}, 1900$, p. 567.

3. Breazeale, J. F.-Effect of Certain Solids upon the Growth of Seedlings in Water Cultures. Botanical Gazette, XLI, 1906, p. 54.

4. Drew, G. H.-The Reproduction and early Development of Laminaria digitata and L. saccharina. Annals of Botany, xxIv, 1910, p. 177.

5. Gill, C. Houghton.-See Van Heurck, H. 21 and 57.

6. Karsten, G.-Die Formänderungen von Sleletonema costatum, Grun., und ihre Abhangigheit von äusseren Faktoren. Wiss, Meeresunters. Kiel. N.F., III, 1898, p. 5.

7. Karsten, G.-Ueber farblose Diatomeen. Flora, Lxxxix, 1901, p. 404.

8. Lockwood, S. M.--Raising Diatoms in the Laboratory. Journ. New York Micr. Soc., 1886, p. 153.

9. Lockwood, S. M.-Aberrant Forms in cultivated Diatoms. Amer. Monthly Micr. Journ., 1893, p. 259.

10. Lockwood, S. M.-Forms anomales chez les Diatomées cultivées artificiellement. Le Diatomiste, II, 1893-96, p. 9. Ann. de Micrographie, x, 1898, p. 1.

11. Miquel, P.-De la Culture artificielle des Diatomées. Le Diatomiste, I, 1890-93, pp. 73, 93, 121, 149, 165. Le Micrographie Préperature, v, 1897, p. 69.

12. Miquel, P.-Recherches expérimentales sur la physiologie, la morphologie, et la pathologie des Diatomées. Ann. de Micrographie, iv, 1891-92, pp. 273, $321,408,529$; v, 1893, pp. 437, 521 ; x, 1898, pp. 49, 177, 182. Le Micro. Préperature, xI, 1903, p. 174 ; xII, 1904, p. 32.

13. Miquel, P.-Du rétablissement de la taille et de la rectification de la forme chez les Diatomées. Le Diatomiste, II, 1893-96, pp. 61, 88.

14. Miquel, P.-Des Spores des Diatomées. Le Diatomiste, II, 1893-6, p. 26.

15. Miquel, P.-Du noyau chez les Diatomées. Le Diatomiste, II, 1893-96, p. 105. Le Micro. Préperature, xII, 1904, p. 167 ; xIII, 1905, p. 83.

16. Richter, O.-Reinkulturen von Diatomeen. Ber. deut. bot. Gesell., xxI, 1903, p. 493.

17. Richter, O.-Ü̈ber Reinkulturen von Diatomeen und die Notwendigkeit der Kieselsäure für Nitzschia palea (Kütz). W. Sm. Verh. d. Gesell. deut. Naturf. u. Äzzte. Breslau, II, 1904, p. 249.

18. Richter, O.-Zur physiologie der Diatomeen. S. B. K. Akad. Wiss. Wien, cxv, 1906, p. 935.

19. Richter, O.-Ueber die Notwendigkeit des Natriums für eine farblose Meeresdiatomee. Wiesner-Festschrift. Wien, 1908, p. 167.

20. Senft, E.-Ueber die Agar-Agar Diatomeen. Zeit. d. Allgem. öst. ApothekerVereines, 1902, n. 9, figs. 1-9. 
21. Van Heurck, H.-Notice biographique sur C. Houghton Gill. Le Diatomiste, II, $1893-96$, p. 125.

22. Van Heurck, H.-Culture des Diatomées. Zeit. f. angew. Mikrosk., III, 1897, pp. 195 and 225.

\section{Rearing.}

23. Agassiz, A.-Revision of the Echini. Cambridge, Mass., 1872-4.

24. Cowles, R. P. Notes on the Rearing of the larvæ of Polygordius. Johns Hopkins Univ. Circulars xxII, No. 161, 1903.

25. Doncaster, L.-On rearing the later stages of Echinoid Larræ. Cambridge Phil. Soc., XII, 1903, p. 48.

26. Grave, C.-A Method of Rearing Marine Larve. Science, N.S. xv, 1902, p. 579 .

27. Lillie, R. S.-The Structure and Development of the Nephridia of Arenicola. Mittheil. Zool. Sta. Neapel., xvII, 1904-6, p. 341.

28. MacBride, E. W.-The Rearing of Larræ of Echinidæ. Reports, Brit. Assoc., Dover, 1899, p. 438.

29. MacBride, E. W.-Notes on the Rearing of Echinoid Larvæ. Journ. Mar. Biol. Assoc., N.S. vi, 1900-3, p. 94.

3". MacBride, E. W.--The Development of Echinus esculentus, together with some points in the Development of $E$. miliaris and E. acutus. Phil. Trans. Roy. Soc., B. cxcv, 1903, p. 285.

31. Theél, H.-On the Development of Echinocyamus pusillus. Nova Acta R. Soc. Sci., Upsala, 1892.

32. Zeleny, C.-The Rearing of Serpulid Larvæ, with Notes on the Behaviour of the Young Animals. Biol. Bull. Woods Holl., virI, 1905, p. 308.

\section{Chemistry.}

33. Dittmar, W.-On the Alkalinity of Ocean Water. Rept. Challenger Expdt., 1873-76, Chem. I, p. 124. London, 1884.

34. Fox, C. J. J.-On the co-efficients of Absorption of the Atmospheric gases in Distilled water and Sea-water. Part II, "Carbonic acid." Publ. de Circonstance. Conseil internat. pour l'expl. de la mer. No. 44. 1909. Copenhagen.

35. van 't Hoff, J. H.-Zur Bildung der ozeanischen Salzablagerungen. Braunschweig, 1905.

36. Knudsen, M.-Hydrography. Danish Ingolf-Expedtn., I, part 2, p. 21, 1899. Copenhagen.

37. Krogh, A.-On the tension of Carbonic Acid in natural waters, and especially in the sea. Meddelelser om Grönland, xxvi, 1904, p. 333. Copenhagen.

38. Raben, E.-Über quantitative Bestimmung von Stickstoffverbindungen in Meerwasser. Wissensch. Meeresunts. Kiel, viii, 1905, pp. 81, 279.

39. Raben, E-—Quantitative Bestimmung der im Meerwasser gelösten Kiselsäure. Wissensch. Meeresunters. Kiel, viII, 1905, p. 99, 286.

40. Ringer, W. E-Die Alkalinitaet des Meereswassers. Verh. uit. Rijksinstituut v.h. onderzoek d. zee, Iv, 1909. Helder.

41. Ringer, W. E., and Klingen, F. I. M. P.-Ü̈ber die Bestinumung von Stickstoffverbindungen im Meereswasser. Verh. uit Rijkinstituut v.h. onderzoek d. zee., I, 1907-8. Helder.

42. Salm, E.-Studie über Indikatoren. Zeitsch. f. Phys. Chemie. LvII, 1906, p. 471 .

43. Tornöe, H.-On the Carbonic acid in Sea-water. Norwegian North-Atlantic Expdt. (1876-8), Chem. II, p. 24. Christiania, 1880. 
General.

44. Baldwin, H. B., and Whipple, G. C.--Observed relations between Oxygen, Carbonic acid, and Algæ growths in Weequahie Lake, Newark, New Jersey. Papers and Repts. Amer. Public Health Assoc., xxxir, 1906.

45. Brandt, K.-Beiträge zur Kenntniss der chemischen Zusammensetzung des Planktons. Wissensch. Meeresunters. Kiel, III, 1898, p. 43.

46. Brandt, K.--Ueber den Stoffwechsel im Meere. Wissensch. Meeresunters. Kiel, Iv, 1899, p. 215 ; vI, 1902, p. 23.

47. Brandt, K.-Ueber die Bedeutung der Stickstoffverbindungen für die produktion in Meere. Beihefte z. Bot. Centralblatt., xvI, 1904.

48. Brandt, K.-On the production and conditions of production in the sea. Rapports et Procès-Verbaux. Conseil internat. pour l'expl. de la mer. III. Appdix. D. Copenhagen, 1905.

49. Gran, H. H.-Diatomeen. Nordisches Plankton. Kiel u. Leipzig, 1908. Botanischer Teil, xIx.

50. Jörgensen, E.-The Protist plankton and diatoms in bottom samples. Hydrographical and Biological Investigations. Bergen, 1906.

51. Klebahn, H.-Ein Überblick über die nenere Diatomeenlitteratur. Archiv. fur Protistenkunde, I, 1902, p. 421.

52. Lemmermann-Bremen, E.-Flagellatæ, Chlorophyceæ, Coccosphærales und Silicoflagellatæ. Nordisches Plankton, Kiel u. Leipzig, 1908. Botanischer Teil, xxI.

53. Oltmanns, F.-Morphologie und Biologie der Algen (with bibliography). Two vols. Jena, 1905.

54. Ostenfeld, C. H.-On the immigration of Biddulphic sinensis, Grev, and its occurrence in the North Sea during 1903-7, etc. Meddelelser fra Komm. for Havundersögelser. Plankton Series I, No. 6, Copenhagen, 1908.

55. Pfeffer, W.-The Physiology of Plants (English edition). Three vols. Oxford, 1900.

56. Smith, G. P. Darnell--_On the oxidation of Ammonia in Sea-water. Journ. Mar. Biol. Assoc., N.S. III, 1893-5, p. 304.

57. Van Heurck, H.-A Treatise on the Diatomaceæ (translated by W. E. Baxter). London, 1896.

58. Vernon, H. M.-The relations between Marine Animal and Vegetable Life. Mittheil. Zool. Sta. Neapel., xIIr, 1893-9, p. 341.

59. Whipple, G. C.-Some experiments on the Growth of Diatoms. Teclnolugy Quarterly, Ix, 1896, p. 145. Boston.

60. Whipple, G. C.-The Microscopy of Drinking Water (and bibliography). New York, 1908.

61. Whipple, G. C., and Jackson, D. D.-Asterionella, its Biography, its Chemistry, and its effect on water supplies. Journ. N.E. Waterworks Assn., xiv, 1899 , p. 1.

62. Whipple, G. C., and Parker, H. N.-On the amount of oxygen and carbonic acid dissolved in natural waters, and the effect of these gases upon the occurrence of microscopic organisms. Trans. Amer. Micr. Soc,, XIIr. 1901-2, p. 103. 